\title{
Seasonal and habitat influences on fish communities within the lower Yasuni River basin of the Ecuadorian Amazon
}

\author{
K. Galacatos ${ }^{\mathrm{a}}$, R. Barriga-Salazar ${ }^{\mathrm{b}} \&$ D.J. Stewart ${ }^{\mathrm{a}}$ \\ ${ }^{a}$ Department of Environmental and Forest Biology, College of Environmental Science and Forestry, \\ State University of New York, Syracuse, NY 13210,U.S.A. (e-mail: katiagalacatos@mindspring.com) \\ ${ }^{\mathrm{b}}$ Escuela Politécnica Nacional, Quito, Ecuador
}

Received 6 May 2002 Accepted 20 December 2003

Key words: neotropical, community structure, floodplain, piscivore-transparency-morphometry (PTM) model

\section{Synopsis}

We sampled lagoon, river and forest stream habitats during the rising water, wet, falling water, and dry seasons in the lowland region of the Yasuni National Reserve in the Ecuadorian Amazon. We collected 195 species, increasing the current number of species for the Napo River basin to approximately 562. The steady rate of species accumulation per sample suggests that the fish fauna is still undersampled. Lagoon, river and forest stream fish communities are highly diverse and variable, composed of common species found within several habitats, of characteristic species found throughout the year, and of seasonally migrating species. Characteristic lagoon species were mainly the curimatids Curimata vittata, Psectrogaster amazonica, Potamorhina altamazonica, P. latior and Cyphocharax plumbeus. The characins Hyphessobrycon copelandi and Hemigrammus cf. lunatus and the catfishes Nemadoras humeralis, Pimelodella sp. C and Sorubim sp. A were characteristic river species. Characteristic forest stream species included Hoplias malabaricus, Hyphessobrycon copelandi, Pimelodella sp. B and Sternopyugus macrurus. During the dry season, lagoon and river habitats had the highest number of individuals and species, as fishes were concentrated in decreasing habitat area. In contrast, stream habitats had the highest species richness and abundance during the rising water and falling water seasons. Species collected included vital food fishes and seasonal migrants. The migratory catfishes Brachyplatystoma vaillantii, Hemisorubim platyrhynchos, Platynematichthys notatus, Platystomatichthys sturio and Sorubim lima were collected during the falling water season, which suggests that these species may begin migrating earlier than expected. These findings highlight the importance of seasonality for both adequately assessing aquatic biodiversity and for developing research and conservation programs encompassing whole river ecosystems.

\section{Introduction}

The flood pulse concept by Junk et al. (1989) proposes that a river, its catchment area, and its floodplain are an ecological unit, and that the majority of riverine production stems from production and nutrient recycling within the floodplain. Thus, species adaptations and life history characteristics suited to flood pulses may be reflected in community structure (Junk et al. 1989). Species collected at a particular site represent a subset of a much larger pool of species. During the dry season, communities may include fishes trapped in a contracting aquatic environment (Lowe-McConnell 1987). While during the wet season, communities may include migratory fishes taking advantage of expanding food and habitat resources. A community can be defined as individuals occurring at the same place and time. This is an ecological entity (Saint-Paul et al. 2000) reflecting the area's floodplain with seasonally expanding and contracting aquatic environment.

Studies on spatial and temporal variation in neotropical fish communities have focused on river (Goulding et al. 1988, Ibarra \& Stewart 1989, Boujard 1992, Jepsen 1997, Stewart et al. 2002), 
stream (Henderson \& Walker 1990, Mérigoux et al. 1998, 1999, Almirón et al. 2000) and lake habitats (Rodríguez \& Lewis 1994, 1997, Galacatos et al. 1996, Henderson \& Crampton 1997, Tejerina-Garro et al. 1998, Saint-Paul et al. 2000, Vono \& Barbosa 2001). In addition, studies have investigated lagoon fishes found within floating macrophyte habitats (Henderson \& Hamilton 1995, Meschiatti et al. 2000), differences among habitats within a localized area (Cox Fernandes 1997, Saint-Paul et al. 2000, Silvano et al. 2000, Petry et al. 2003), and differences between natural and flow-regulated rivers (Mérigoux \& Ponton 1999). Fish communities within floodplain rivers and lakes are influenced not only by water type (Marlier 1967, Galacatos et al. 1996, Saint-Paul et al. 2000) but also by turbidity, substrate, $\mathrm{pH}$, depth and flow (Goulding et al. 1988, Ibarra \& Stewart 1989, Boujard 1992, Cox Fernandes 1997). Neotropical stream fishes appear to be influenced by the abiotic factors of stream width (Angermeier \& Karr 1983), sunlight (Power 1983), conductivity (Almirón et al. 2000), habitat diversity (Gorman \& Karr 1978, Mérigoux et al. 1998) and the biotic factors of predation (Power 1984), herbivory (Wootton \& Oemke 1992) and competition (Zaret \& Rand 1971).

Ichthyological studies within the Ecuadorian Amazon have described the habitat and food preferences of fishes of the upper Rio Aguarico (Saul 1975). Dry season sampling has documented the Napo River drainage diversity (Stewart et al. 1987) as well as fish community patterns for riverine sandy beaches (Ibarra \& Stewart 1989), lagoon and associated tributaries (Galacatos et al. 1996) and deep river and adjacent sandy beach habitats (Stewart et al. 2002).

Many of the above mentioned studies indicate highly variable stochastic fish communities (Lowe-McConnell 1987, Goulding et al. 1988, Jepsen 1997, Saint-Paul et al. 2000). However, most of these studies have limited temporal and geographic scales. As temperate studies of community structure have demonstrated, conclusions drawn from studies with extended temporal and geographic scales can differ significantly from conclusions drawn from short term and localized studies (Jackson \& Harvey 1989, Strange et al. 1992, Keast 1996, Angermeier \& Winston 1998, Gehrke \& Harris 2000). Indeed, recent studies within the Venezuelan llanos with expanded spatial (Rodríguez \& Lewis 1994, 1997) and temporal scale (Winemiller 1996) indicate that fish communities may be nonrandom, with both deterministic and stochastic processes operating.
In particular, Rodríguez \& Lewis (1997) proposed the piscivore-transparency-morphometry (PTM) model for predicting floodplain lake fish assemblage patterns. The PTM model predicts that lake water transparency can largely determine the presence of major taxa and piscivore types. For example, during the dry season as water transparency decreases, the number of visually-oriented fishes, such as characiforms, cichlids and clupeomorphs, should decrease relative to nocturnal and sensory adapted piscivores, such as catfishes and knifefishes. Tejerina-Garro et al. (1998) further proposed that the PTM model also may apply to the fish communities of the Vinces River flooplain in western Ecuador.

The present study examines the seasonal occurrence of fish species within and among lagoon, river and forest stream habitats in the lower Yasuni River basin, Yasuni National Park, eastern Ecuador. We tested the following hypotheses: (1) lagoon, river and forest stream habitats have distinct fish communities; (2) fish communities within each habitat are influenced by rainfall seasonality; and (3) the PTM model (Rodríguez \& Lewis 1997) will predict the dry season lagoon fish community.

\section{Study sites}

We conducted this study in the Yasuni National Reserve (Figure 1), which comprises 982000 ha and is the largest nature preserve in Ecuador. We collected fishes from four sites representative of three habitat types: lagoon, river and stream. Site one, Jatuncocha Lagoon $\left(0^{\circ} 59^{\prime} 46.2^{\prime \prime} \mathrm{S}\right.$, $75^{\circ} 26^{\prime} 59.8^{\prime \prime} \mathrm{W}$ ), is a large shallow blackwater lagoon connected to the Yasuni River via the blackwater Jatuncocha River. Site two, Yasuni River (0 $0^{\circ} 9^{\prime} 37.9^{\prime \prime} S$, $75^{\circ} 25^{\prime} 59.1^{\prime \prime} \mathrm{W}$ ), is a major tributary of the Napo River that varies seasonally between conditions close to blackwater and those approaching whitewater. Sites three and four, Cotoyacu $\left(1^{\circ} 00^{\prime} 34.7^{\prime \prime} \mathrm{S}, 75^{\circ} 26^{\prime} 15.1^{\prime \prime} \mathrm{W}\right)$ and Tambococha $\left(0^{\circ} 58^{\prime} 32.6^{\prime \prime} \mathrm{S}, 75^{\circ} 25^{\prime} 29.5^{\prime \prime} \mathrm{W}\right)$, are groundwater-fed forest streams. Cotoyacu drains into the Yasuni River, while Tambococha drains into the blackwater Tambococha River. Jatuncocha Lagoon and Streams Cotoyacu and Tambococha are flooded blackwater habitats during the wet season.

Rainfall data collected over 13 years by the Instituto Nacional de Meteorologia e Hidrologia at Nuevo Rocafuerte reveals a dry season between December and February, and a wet season between May and June, 

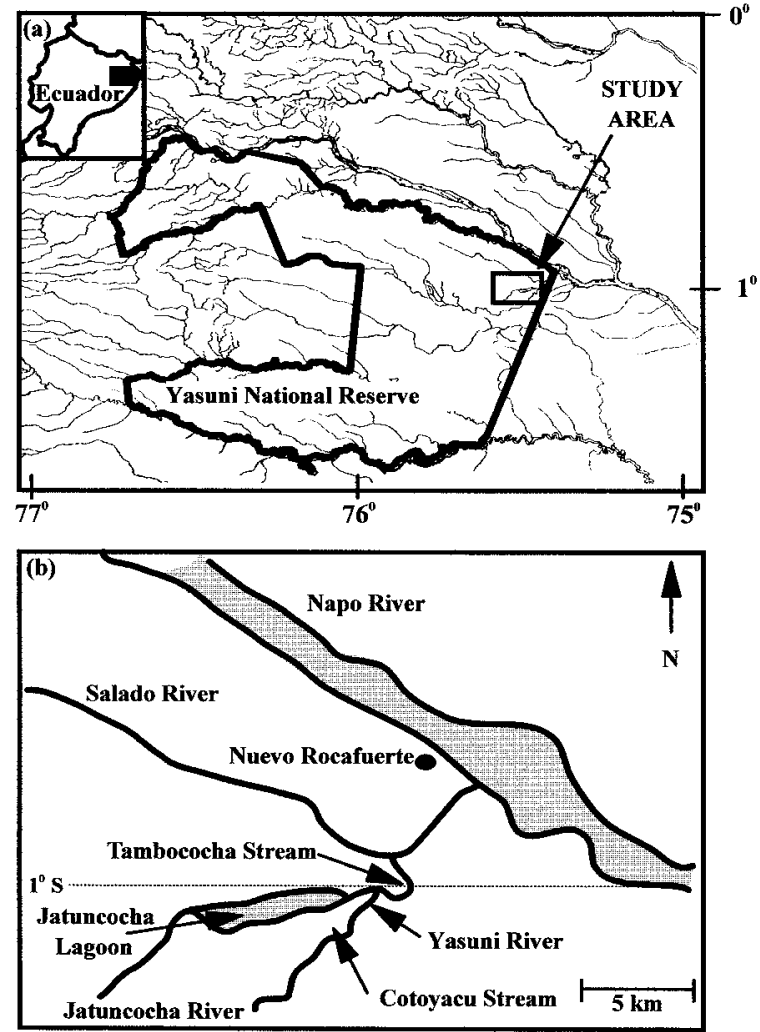

Figure 1. Study area in the Ecuadorian Amazon shown as (a) area within the Yasuni National Reserve of the Ecuadorian Amazon and (b) as schematic of study sites.

with intervening rising water and falling water seasons (Figure 2). Rainfall is highly variable (Figures 2 and 3) with the greatest relative monthly variation occurring during the dry season (Figure 3). Rainfall variability affects both the onset and duration of the wet and dry seasons.

In addition, unpredictable and heavy rainfall in local and upland regions results in rapid fluctuations in water chemistry, velocity and depth. For example, following heavy upland rainfall, the consequent heavy discharge may overwhelm the Napo and Yasuni river channels and cause whitewater to back flow into blackwater habitats like Jatuncocha Lagoon. Conversely, localized rainfall may increase blackwater discharges into whitewater habitats. Accordingly, blackwater and whitewater habitats not only occur within close proximity, but also may mix their flows at variable junctures. Unlike the predictable monomodal flood pulse and large flood amplitude associated with larger rivers and floodplains, the lower Yasuni experiences unpredictable, polymodal flood pulses associated with rainfall in headwater regions.

\section{Materials and methods}

\section{Sampling}

We sampled during four periods: rising water, February 1996; wet season, June 1996; falling water season, November 1996; and dry season, February 1997 (Figure 2). We used two gill nets in the lagoon and river and one gill net for each stream site. We used six baited minnow traps in each site. We set gill nets and minnow traps at dusk (17:00-18:00 h) each evening and fishes were collected at dawn (05:00-06:00 h). Gill nets were $1.83 \mathrm{~m}$ high with six $7.62 \mathrm{~m}$ long panels of $25.4,50.6$, $63.5,76.2,88.9$ and $101.6 \mathrm{~mm}$ stretch mesh sizes, and were weighted to fish along the bottom. In addition, we set six baited minnow traps at each site. We preserved fishes in $10 \%$ formalin in the field, transferred them to $70 \%$ ethanol and deposited them in the Museo de la Escuela Politécnica Nacional (MEPN) in Quito, Ecuador.

\section{Environmental variables}

We took five measurements of temperature, dissolved oxygen, $\mathrm{pH}$, turbidity and conductivity in all sites (Solomat 520c multifunctional chemistry and water quality monitor) for three seasons: rising water, wet and dry seasons. We used MANOVA (Statistica, version 5.1, StatSoft, Inc. 1998) to test the significance of seasonality and water chemistry variables within the lagoon, river and stream habitats.

\section{Community analyses}

We calculated species accumulation curves for all samples with BioDiversity Professional Program (McAleece et al. 1997) to assess effectiveness of sampling species richness within the study area. We estimated species dominance and richness within each study site by Simpson's Diversity Index, evenness and rarefaction. Simpson's Diversity Index (Simpson 1949) measures the probability that two randomly drawn individuals from an infinitely large community belong to different species. Simpson's Diversity Index is a widely used dominance measure, weighted towards the abundance of the commonest species and with low 


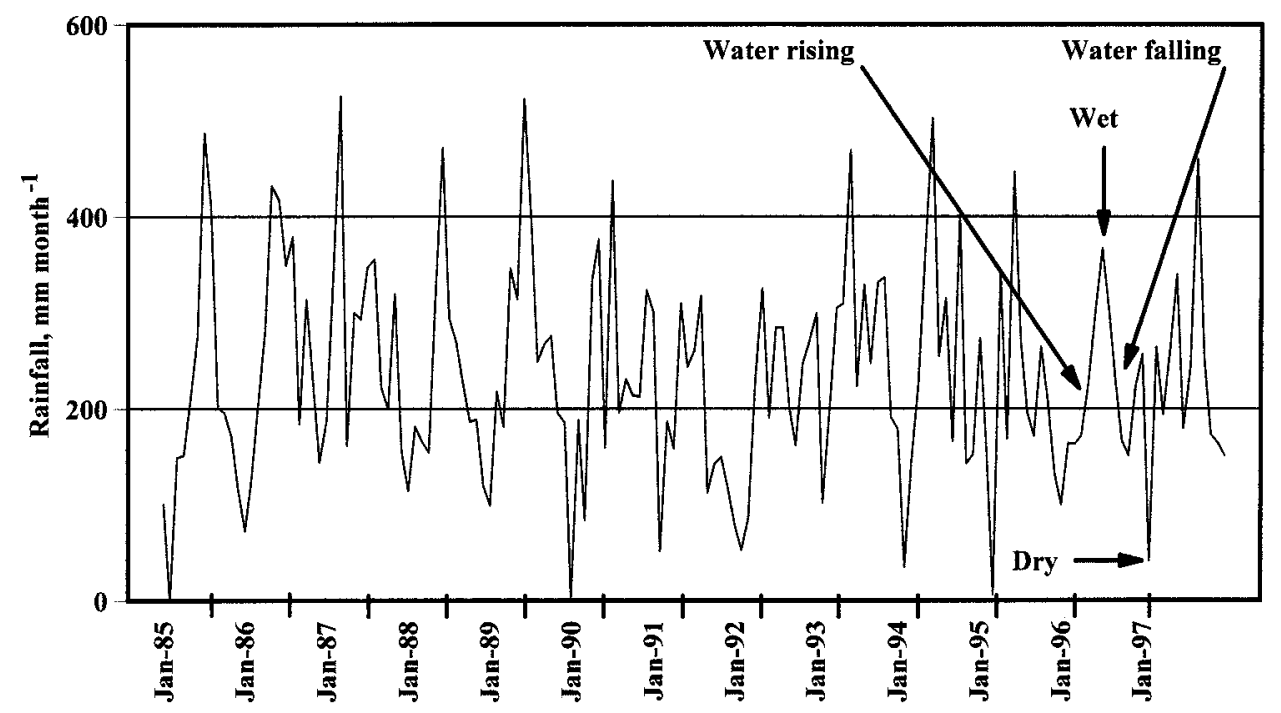

Figure 2. Total monthly rainfall (mm) December 1984 through December 1997, measured at Nuevo Rocafuerte. Sampling periods: rising water season, February 1996; wet season, June 1996; falling water season, November 1996 and dry season, February 1997.

sensitivity to sample size (Magurran 1988). We calculated evenness as the proportional abundance of each species to the total site diversity (Hill 1973). Rarefaction enables the comparison of richness in terms of expected number of species per sample among samples with different numbers of individuals. This method was proposed by Sanders (1968) and corrected by Hurlbert (1971) and Simberloff (1972). We calculated the expected number of species per sample using the EcoSim program (Gotelli \& Entsminger 2001) with sample size standardized to the smallest sample size.

We used multivariate analyses of non-metric multidimensional scaling ordination (NMS) and Bray-Curtis hierarchical clustering to compare species composition among habitats, $\beta$ diversity and seasons. We used PC-ORD version 4 for all three analyses (McCune \& Mefford 1999). Species abundances were $\log _{10}(x+1)$ transformed to reduce the influence of nonnormal data. We standardized water chemistry variables to zero mean and unit variance to compare variables with different scales (Jongman et al. 1995). In addition, we used NMS to examine the correlation between species composition and water chemistry variables among samples for the rising water, wet and dry seasons.

Non-metric multidimensional scaling is an ordination technique based on ranking similarities between samples. The resulting ordination reflects the relative similarity of species composition, among samples (Clarke 1993). Monotonicity, NMS's only assumption, is the linear relationship between original sample distance and first ordination axis distances. Unlike ordination techniques based on gradient analysis, such as detrended correspondence analysis (DCA) and canonical correspondence analysis (CCA), NMS does not assume model or linear responses of either species or environmental variables. Therefore, NMS can be used with large, highly skewed species matrices typical of high diversity systems (Clarke 1993). In addition because no linear response is assumed, NMS also performs well in assessing community change with repeated samples within small geographic scales. To verify NMS ordination groupings we paired NMS ordinations with Bray-Curtis clustering using weighted group averaging (UPGMA) to link groups and Sorenson's percent similarity to scale the dendrogram (Clarke 1993).

\section{Results}

\section{Environmental variables}

Seasonality of temperature, dissolved oxygen, $\mathrm{pH}$, conductivity and turbidity (Table 1) were significantly different among the study sites $(\mathrm{df}=3, \mathrm{~F}=2.83$, 

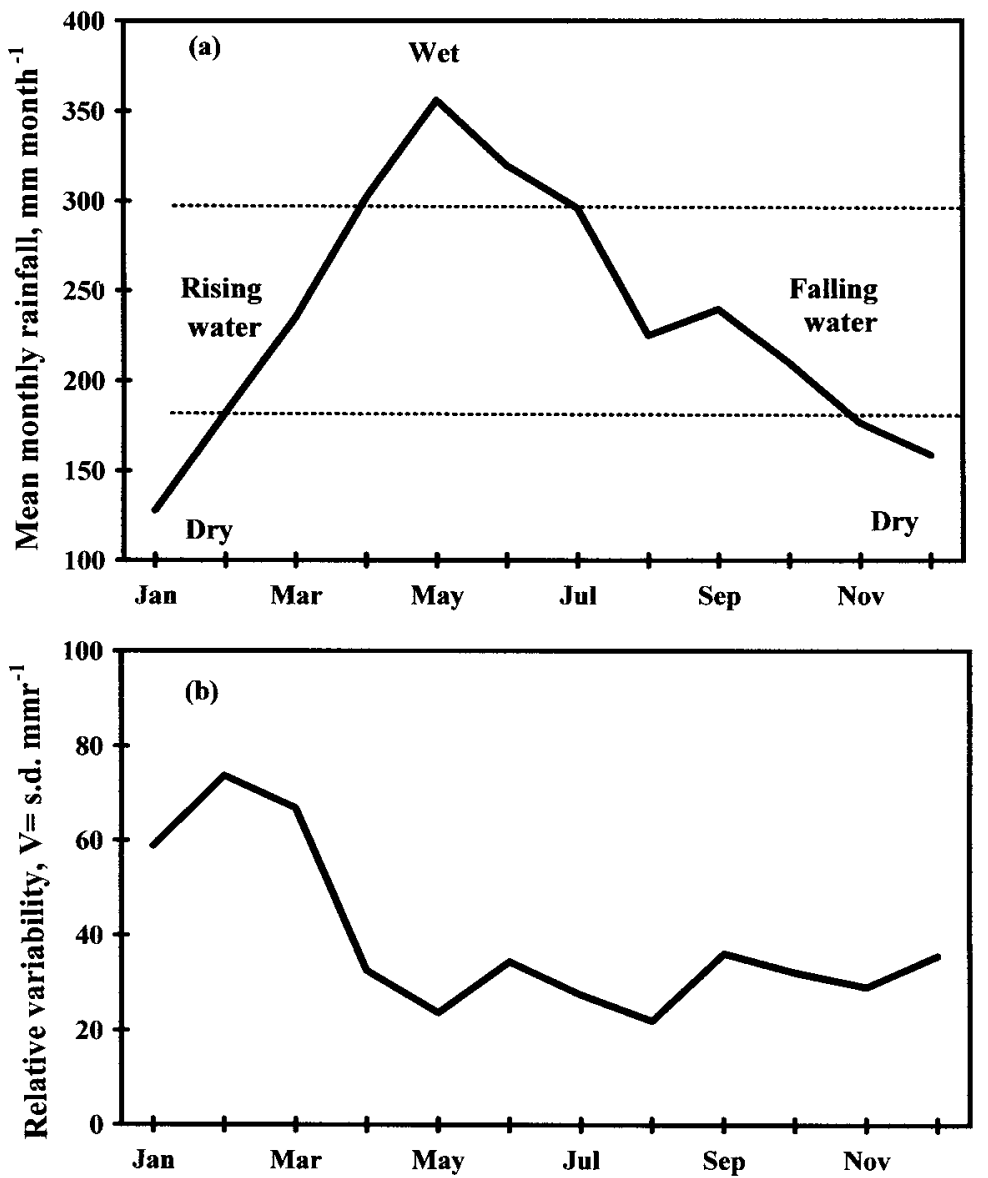

Figure 3. Monthly rainfall recorded at Nuevo Rocafuerte, December 1984 through December 1997 shown as (a) mean monthly rainfall $(\mathrm{mm})$ and (b) relative variability in monthly rainfall, V, calculated from December 1984 through December 1997, where sd = standard deviation in monthly rainfall and $\mathrm{mmr}=$ mean monthly rainfall in $\mathrm{mm}$ (Hayward \& Oguntoyinbo 1987).

$\mathrm{p}=0.047)$. The blackwater lagoon had higher water temperatures, lower $\mathrm{pH}$ and lower conductivity than the Yasuni River and forest streams throughout all three seasons. In the lagoon, turbidity was low during the wet season, intermediate during the rising water season, and high during the dry season. River temperature and turbidity rose during the dry season, while dissolved oxygen and $\mathrm{pH}$ rose during the wet season. Similar seasonal changes in water chemistry occurred in streams Cotoyacu and Tambococha. During the wet season, the streams were blackwater habitats expanding into the forest with lower temperature and conductivity and higher dissolved oxygen and $\mathrm{pH}$ compared to rising water, falling water and dry seasons. During the dry season the streams were reduced to pools with low dissolved oxygen and high turbidity.

\section{Community analyses}

We collected 4305 individuals from 195 species and 35 families (Appendix 1). This study increased the number of species recorded for the lower Yasuni River basin from 136 to 277 species and the number of species recorded for the Napo River to 562 species. In our collections $71 \%$ of the species belonged to three families: $50 \%$ characids, $12 \%$ pimelodids and $9 \%$ curimatids. The rate of species accumulation per additional sample was still increasing after pooling the 16 samples from all sites (Figure 4). Abundance, species richness, rarefied species richness, diversity, evenness and the percent of species and individuals varied among habitats and seasonally within each site (Figures 5 and 6). 
Table 1. Mean and standard deviation for water chemistry variables measured during rising water, wet and dry seasons within lagoon, river and stream sites.

\begin{tabular}{lllllr}
\hline Study site & $\begin{array}{l}\text { Temperature } \\
\left({ }^{\circ} \mathrm{C}\right)\end{array}$ & \multicolumn{1}{l}{$\begin{array}{l}\text { D.O. } \\
\left(\mathrm{mg} \mathrm{l}^{-1}\right)\end{array}$} & $\mathrm{pH}$ & $\begin{array}{l}\text { Conductivity } \\
\left(\mu \mathrm{S} \mathrm{cm}^{-1}\right)\end{array}$ & \multicolumn{1}{l}{$\begin{array}{l}\text { Turbidity } \\
(\mathrm{NTU})\end{array}$} \\
\hline Jatuncocha Lagoon & & & & & \\
$\quad$ Rising water & $28.6 \pm 0.6$ & $7.7 \pm 0.1$ & $4.7 \pm 0.1$ & $10.1 \pm 0.2$ & $48.3 \pm 2.7$ \\
$\quad$ Wet & $27.8 \pm 1.1$ & $7.6 \pm 0.1$ & $4.7 \pm 0.1$ & $10.5 \pm 0.6$ & $18.1 \pm 3.0$ \\
$\quad$ Dry & $27.7 \pm 0.2$ & $8.8 \pm 0.8$ & $5.5 \pm 0.2$ & $14.7 \pm 0.1$ & $77.2 \pm 0.9$ \\
Yasuni River & & & & \\
$\quad$ Rising water & $25.1 \pm 0.6$ & $7.6 \pm 0.2$ & $5.7 \pm 0.1$ & $19.6 \pm 0.9$ & $23.1 \pm 3.3$ \\
$\quad$ Wet & $25.3 \pm 0.3$ & $8.6 \pm 0.5$ & $6.8 \pm 0.1$ & $18.8 \pm 0.4$ & $20.7 \pm 4.6$ \\
$\quad$ Dry & $26.5 \pm 0.2$ & $6.8 \pm 0.1$ & $5.7 \pm 0.1$ & $20.5 \pm 1.5$ & $47.0 \pm 2.6$ \\
Cotoyacu Stream & & & & & \\
$\quad$ Rising water & $25.8 \pm 0.3$ & $7.5 \pm 1.0$ & $6.0 \pm 0.2$ & $27.6 \pm 1.5$ & $32.6 \pm 6.3$ \\
$\quad$ Wet & $24.7 \pm 0.4$ & $10.9 \pm 0.2$ & $6.2 \pm 0.3$ & $20.8 \pm 1.1$ & $28.7 \pm 5.7$ \\
$\quad$ Dry & $26.6 \pm 0.5$ & $0.9 \pm 0.1$ & $6.1 \pm 0.2$ & $66.6 \pm 11.6$ & $63.9 \pm 4.8$ \\
Tambococha Stream & & & & \\
$\quad$ Rising water & $25.9 \pm 0.1$ & $9.2 \pm 0.8$ & $5.5 \pm 0.1$ & $28.4 \pm 0.9$ & $12.4 \pm 1.5$ \\
$\quad$ Wet & $24.6 \pm 0.3$ & $10.9 \pm 0.6$ & $6.2 \pm 0.3$ & $20.8 \pm 1.1$ & $31.6 \pm 3.9$ \\
$\quad$ Dry & $26.2 \pm 0.7$ & $1.1 \pm 0.1$ & $5.9 \pm 0.3$ & $58.9 \pm 5.4$ & $115.6 \pm 5.4$ \\
\hline
\end{tabular}

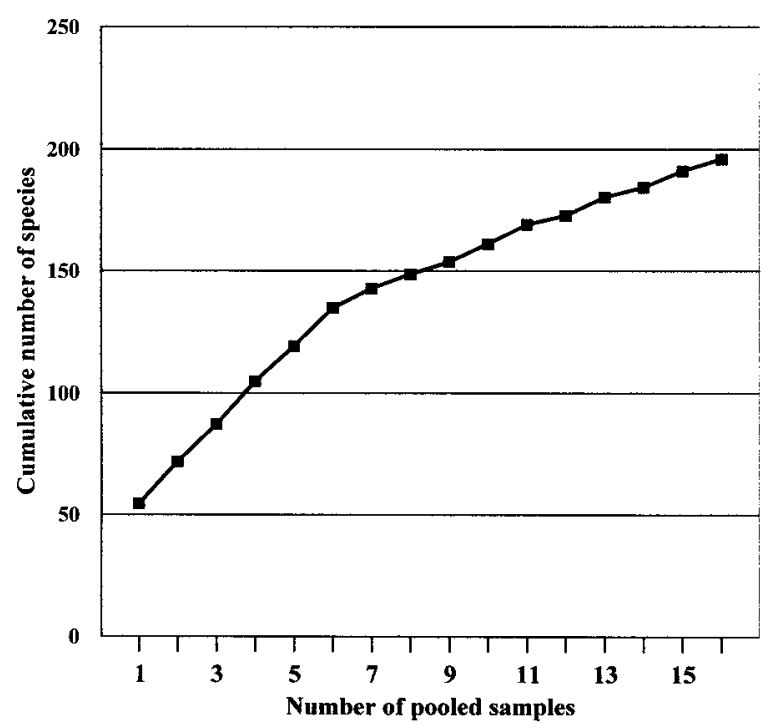

Figure 4. Cumulative number of species per each additional sample. Analysis randomly pools the samples and examines how species accumulate as samples are pooled. When asymptote is reached most of the species in a region have been collected.

Species richness was high during the dry season in both Jatuncocha Lagoon (70 species) and Yasuni River (74 species). Yasuni River diversity and evenness were lowest during the rising water sampling period and remained high for the three remaining sampling periods. In contrast, Jatuncocha Lagoon species diversity and evenness were highest in the rising water sampling period and then decreased throughout the remainder of the sampling year. Sampling within both streams was also variable. Within Cotoyacu Stream, species richness was highest during the wet season sampling period, while species diversity was constant throughout the year. Within Tambococha Stream, species richness was highest during the rising water sampling period and decreased throughout the remainder of the sampling year.

Rarefied species richness estimates were not always consistent among either habitats or seasons (Figure 5). The highest rarefied richness estimates occurred during the rising water season in the lagoon, the wet season in Cotoyacu Stream and the falling water season in the river and Tambococha Stream. The lowest rarefied species richness occurred in the falling water season for the river and in the dry season for the lagoon and streams.

Species diversity and evenness of Tambococha Stream were highest during the wet and falling water sampling periods. Rare species, single individual per species encountered, comprised $32 \%$ or $16 \%$ of the total 195 species collected. Of these, 13 were collected from Yasuni River, 6 from Jatuncocha Lagoon, 9 from Cotoyacu Stream and 4 from Tambococha Stream. In addition, the number of single specimens per sample was variable and at times comprised approximately half 

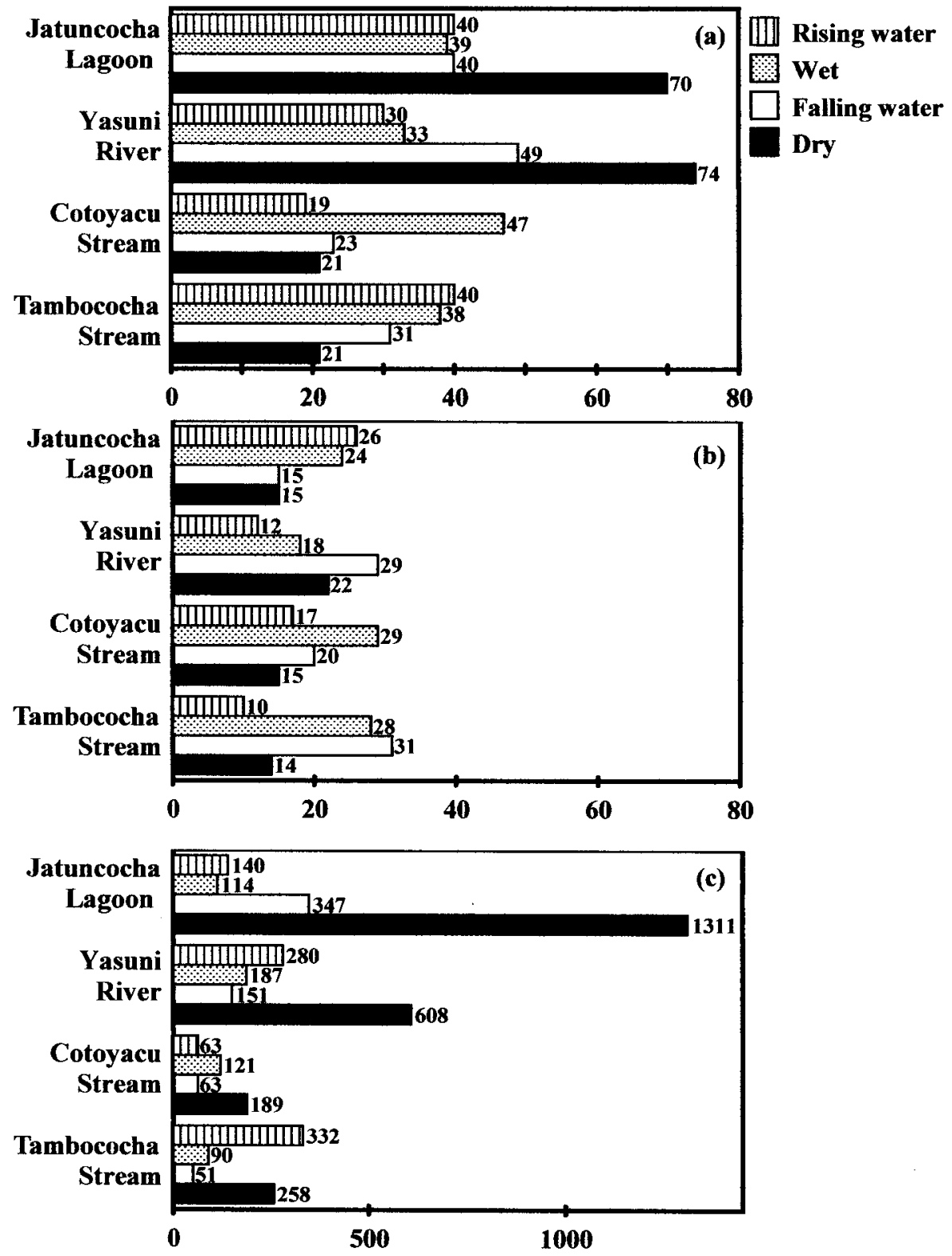

Figure 5. Seasonality of (a) number of species, (b) rarefied number of species and (c) number of individuals in various habitats of the lower Yasuni River system.

the species collected per site: $24-49 \%$ from Jatuncocha Lagoon, 32-45\% from Yasuni River, 24-63\% for Cotoyacu Stream and 14-63\% from Tambococha Stream.

Lowland habitats can be characterized by the resident species caught throughout the sampling year (Table 2). Some of these resident species were ubiquitous, such as the piscivores Hoplias malabaricus, Hydrolycus pectoralis, Rhaphiodon vulpinus, Pimelodella sp. $\mathrm{B}$ and Plagioscion squamosissimus and the herbivore Mylossoma duriventris. The lagoon was further characterized by the curimatid species Curimata vittata, Psectrogaster amazonica, Potamorhina altamazonica, P. latior and 

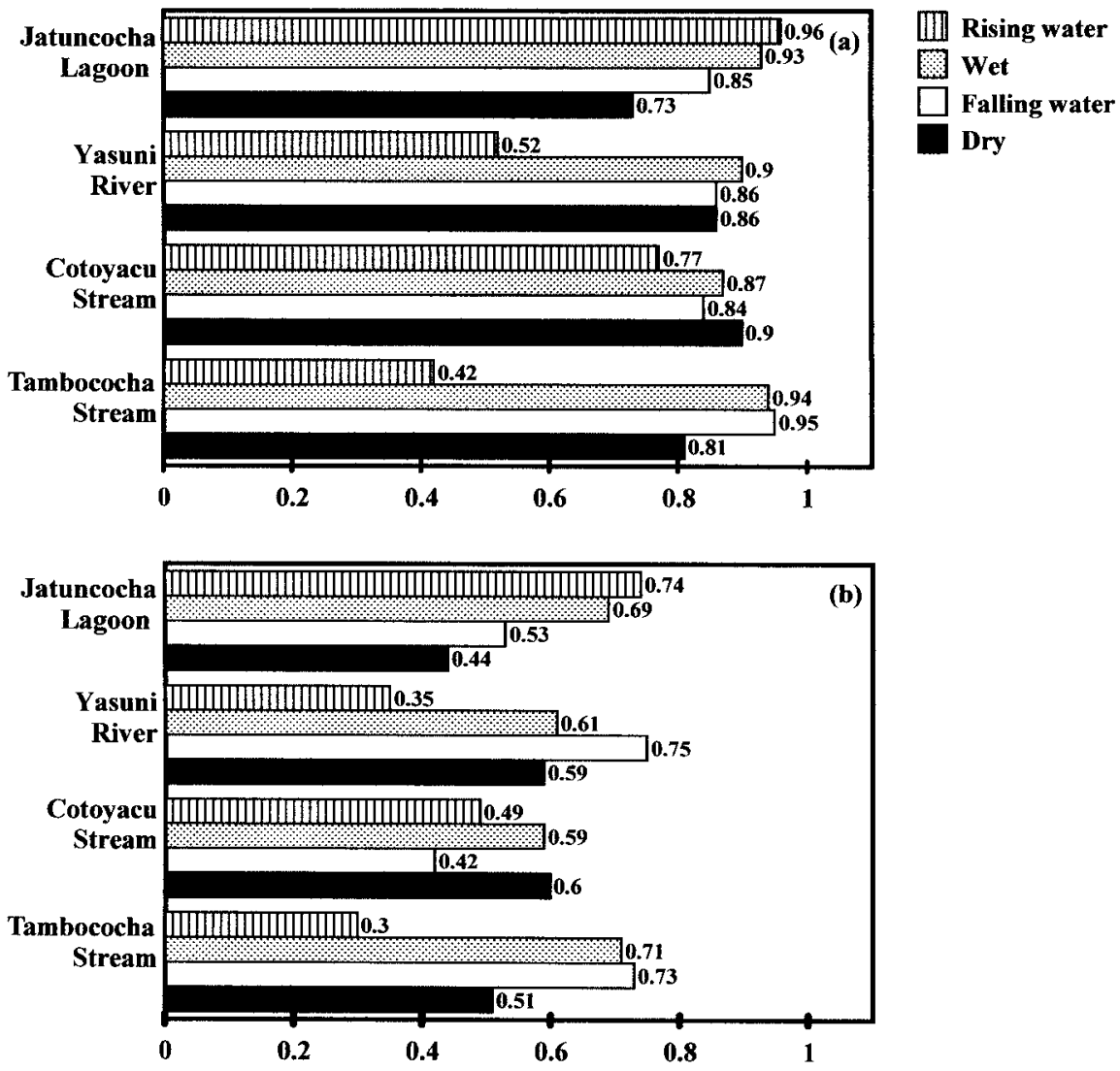

Figure 6. Seasonality of (a) Simpson's Diversity Index and (b) eveness in various habitats of the lower Yasuni River system.

Cyphocharax plumbeus. Resident species within the river included the characins Hyphessobrycon copelandi and Hemigrammus cf. lunatus and the catfishes Nemadoras humeralis, Pimelodella sp. G and Sorubim sp. A. Cotoyacu Stream's six resident species were either common lowland species or species also found in Tambococha Stream. By contrast, the 10 resident species of Tambococha Stream included Ancistrus cf. alga and Hypselecara temporalis, which were found only at this site.

Habitat and seasonal variation of species composition can also be examined by comparing the percent abundance of individuals within the families Characidae, Curimatidae, Doradidae, Auchenipteridae, Pimelodidae, Loricariidae and Cichlidae (Figure 7). Seasonal species composition varied not only among habitats but also seasonally within habitats.

Seasonality within the Jatuncocha Lagoon was marked by a shift in the relative abundance of characids and curimatids. Comprising from
$40 \%$ to $82 \%$ of the individuals, curimatids such as Psectrogaster amazonica, P. essequibensis and Curimata roseni were most abundant during the rising water, wet and falling water seasons. Comprising $82 \%$ of the individuals, characids, including Hyphessobrycon copelandi, Hemigrammus cf. lunatus, $H$. cupreus, H. unilineatus, Phenacogaster sp. and Poptella compressa were most abundant during the dry season. In addition, the percent abundance of individuals for ageneiosid, auchenipterid and doradid catfishes increased during the rising water and wet seasons to $31 \%$ and $19 \%$, respectively.

Characids and catfishes varied seasonally within Yasuni River. Characids appeared to be most numerous during the rising water season, comprising $75 \%$ of the individuals; however, this sample was dominated by the small characin Hyphessobrycon copelandi that comprised $68 \%$ of the individuals. Catfishes were most numerous during the wet and falling water seasons, comprising $56 \%$ and $38 \%$ of the individuals, 
Table 2. Characteristic species found throughout all sampling periods within lagoon, river and stream habitats of the lower Yasuni River system.

\begin{tabular}{llll}
\hline Jatuncocha Lagoon & Yasuni River & Cotoyacu Stream & Tambococha Stream \\
\hline Anodus sp. A & Hyphessobrycon copelandi & Hoplerythrinus unitaeniatus & Hoplias malabaricus \\
Hemiodus unimaculatus & Hemigrammus cf. lunatus & Hoplias malabaricus & Erythrinus erythrinus \\
Curimata vittata & Phenacogaster sp. & Charax caudimaculatus & Parauchenipterus galeatus \\
Cyphocharax plumbeus & Nemadoras humeralis & Pimelodella sp. B & Ancistrus cf. alga \\
Potamorhina altamazonica & Ageneiosus ucayalensis & Sternopygus macrurus & Curimatella alburna \\
Potamorhina latior & Ageneiosus inermis & Rhamdia sp. & Hyphessobrycon copelandi \\
Psectrogaster amazonica & Centromochlus heckelii & & Hypselecara temporalis \\
Psectrogaster essequibensis & Pimelodella sp. B & & Ancanthodoras spinosissimus \\
Pygocentrus nattereri & Pimelodella sp. C & Gymnotus carapo \\
Nemadoras humeralis & Sorubim sp. A & Pimelodella sp. B \\
Triportheus albus & Hypostomus emarginatus & & \\
Rhaphiodon vulpinus & Plagioscion squamosissimus & & \\
Plagioscion squamosissimus & & & \\
\hline
\end{tabular}

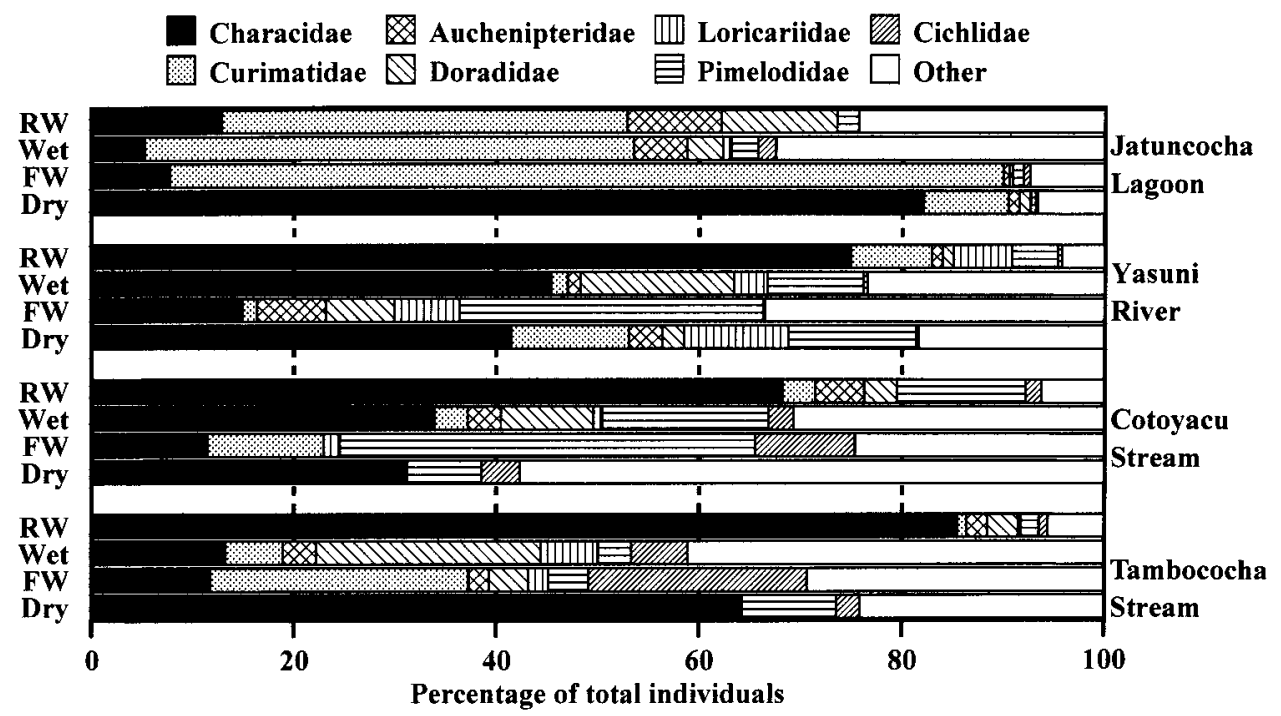

Figure 7. Seasonal variation in dominant families represented as percentage of total individuals per sample. Legend follows: RW - rising water, dry, FW - falling water and wet seasons.

respectively. Pimelodids such as Pimelodella sp. were most abundant during the wet $(12 \%)$ and falling water $(27 \%)$ seasons while the doradids, such as Nemadoras humeralis and $N$. trimaculatus, were most abundant during the wet season (20\%). Loricariid abundance was highest $(17 \%)$ during the falling water season.

Seasonality in Cotoyacu and Tambococha Streams was primarily characterized by shifts in the abundance of characids. During the rising water season, characids such as Hyphessobrycon copelandi, were most abundant in both streams, comprising $68 \%$ of the individuals in Cotoyacu and $86 \%$ in Tambococha. Characids were least abundant during the falling water season, comprising only $12 \%$ of the individuals in both streams. Curimatids were most abundant during the falling water season in Cotoyacu (12\%) and Tambococha (26\%) and entirely absent during the dry season. Callichthyids and doradids were most abundant during the wet season in Tambococha, comprising $21 \%$ and $22 \%$, respectively. While in Cotoyacu, pimelodid relative abundance rose to the highest level, $41 \%$, during the falling water season. Cichlid abundance was highest in the falling water season sample for 

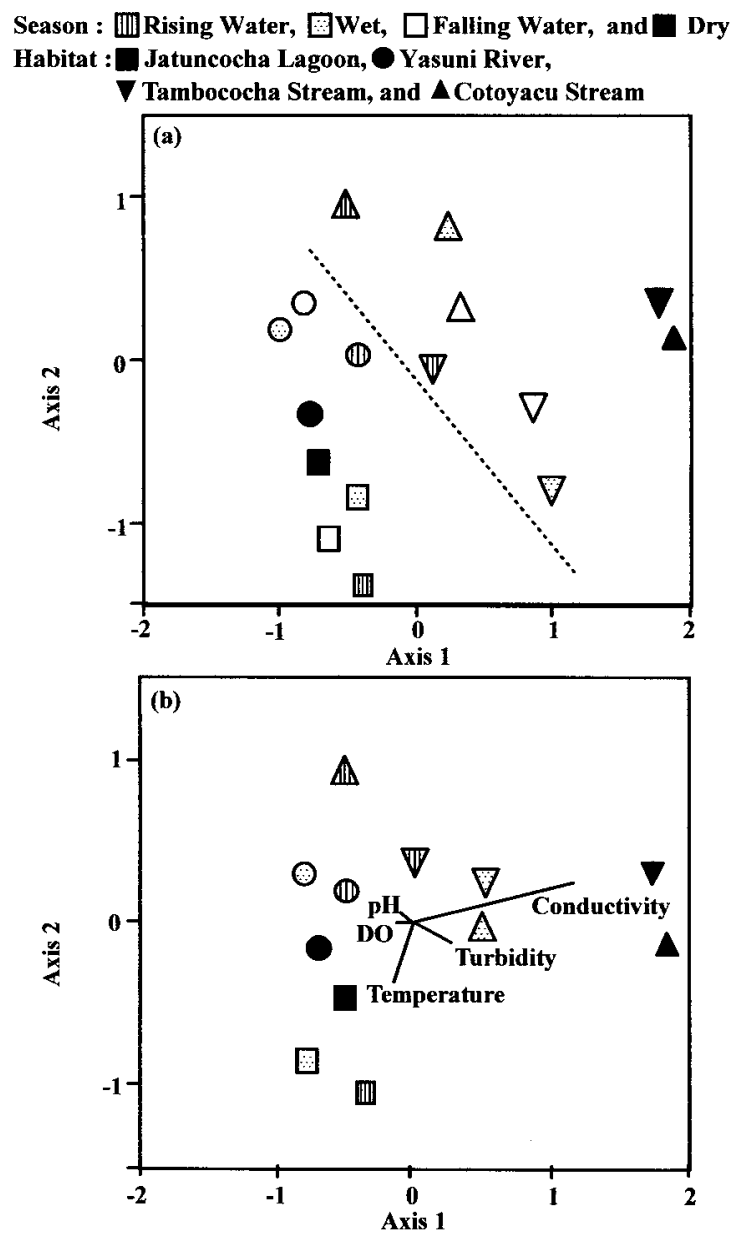

Figure 8. (a) Non-metric multidimensional scaling ordination of all 16 fish community samples. Samples grouped along axis 1 primarily by habitat type. The dashed line separates the stream samples from the lagoon and river samples. (b) Non-metric multidimensional scaling ordination of 12 fish community samples with biplot of water chemistry variables of temperature, turbidity, conductivity, $\mathrm{pH}$ and dissolved oxygen (DO).

both streams, with $10 \%$ in Cotoyacu and $22 \%$ in Tambococha.

We performed NMS first, on all 16 samples collected from the lagoon, river and two stream sites and, second, on the 12 samples with corresponding water chemistry variables from the rising water, wet and dry seasons (Figure 8). Both NMS ordinations had monotonocity, with high cumulative coefficients between ordination distances and the distances in the original $n$-dimensional space: NMS ordination of 16 samples had a cumulative $r^{2}=0.82\left(r^{2}=0.53\right.$ for axis-1 and 0.21 for axis-2); and NMS ordination of 12 samples with water chemistry variables had a cumulative $r^{2}=0.86\left(r^{2}=0.56\right.$ for axis- 1 and 0.30 for axis-2).
The NMS ordination and Bray-Curtis clustering of the 16 sites resulted in similar groupings, based primarily on habitat and secondarily on season (Figures 8 and 9). Within the ordination, the dry season samples were the most distinct group, followed by the rising water, wet and falling water season stream samples. The rising water, wet and falling water season river samples grouped together. The dry season river sample grouped between the other river samples and the lagoon samples. Within the Bray-Curtis dendrogram the overall similarity among groups was low. The dry season stream group, forming the first branch of the dendrogram, had $9 \%$ similarity to all other samples. The second branching within the dendrogram contained the falling water and wet season stream 


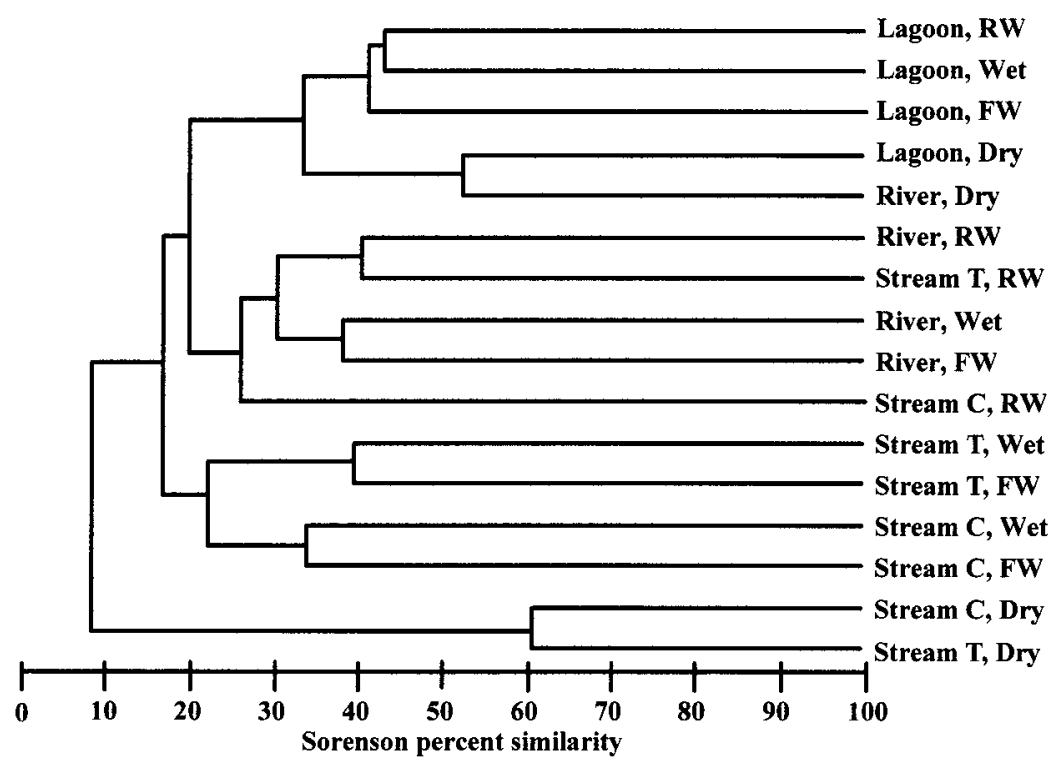

Figure 9. Bray-Curtis hierarchical clustering of all 16 fish community samples. Dendrogram scaled with Sorenson percent similarity. Legend follows: Lagoon - Jatuncocha, River - Yasuni, Stream T - Tambococha Stream, Stream C - Cotoyacu Stream, RW - rising water, wet, FW - falling water and dry seasons.

samples and had $18 \%$ similarity to the remaining rising water stream, river and lagoon samples. The third dendrogram branch had $21 \%$ similarity and separated the group consisting of the rising water season stream samples and the rising water, wet and falling water season river samples from the group consisting of the lagoon and dry season river samples. The fourth branch with $27 \%$ similarity separated the rising water season Cotoyacu Stream sample from the rising water, wet and falling water season river samples.

The dry season lagoon and river grouping was comprised of a large number (40) of shared species. For example, the characins Hyphessobrycon copelandi, Hemigrammus cf. lunatus, Phenacogaster sp. and Triportheus angulatus and the piscivore Ageneiosus inermis were very abundant in both lagoon and river dry season samples. In addition, the curimatids, Curimata vittata, Cyphocharax laticlavius, C. plumbeus, C. spiluropsis, Potamorhina latior and $P$. altamazonica were found year long within the lagoon and in the dry season river sample.

The highest within group similarity occurred for the dry season stream samples $(60 \%)$ and the dry season lagoon and river samples (52\%). Moderate to low similarity occurred between the falling water and wet season sample pairs for Cotoyacu Stream (33\%), Tambococha Stream (39\%) and Yasuni River (38\%). The rising water Tambococha Stream and Yasuni River had $41 \%$ similarity. The rising water, wet and falling water season lagoon samples had $42 \%$ similarity.

The NMS ordination of the rising water, wet and dry season samples with water chemistry variables revealed similar groupings with the NMS of all 16 samples and the correlation of habitat and water chemistry variables (Figure 8). High conductivity was associated with the desiccating pools of the dry season stream samples. Higher dissolved oxygen and $\mathrm{pH}$ were associated with all Yasuni River samples and the rising water stream samples. Jatuncocha Lagoon had high temperatures throughout the three seasons.

\section{Piscivore-Transparency-Morphometry (PTM) model}

To test the PTM model, we calculated the percent abundances of characiform and siluriform individuals within Jatuncocha Lagoon. The dry season sampling occurred at the end of the dry season, when water levels within the Jatuncocha Lagoon were lowest and turbidity highest (Table 1). The siluriforms were abundant during both the wet and dry season, while the characiforms were most abundant during the falling water and dry seasons. Furthermore, the characiform piscivores Pygocentrus nattereri and Rhaphiodon vulpinus were common, characteristic lagoon species encountered during all seasons. 


\section{Discussion}

\section{Environmental variables}

Seasonal changes in environmental variables reflected the wet season expansion and dry season contraction of lagoon and stream habitats. However, the changes within the Yasuni River may have been, in part, influenced by water inputs from other habitats. For example, the temperature and turbidity increases noted for the Yasuni River during the dry season, may have been influenced by the inflow of the blackwater Jatuncocha River. During the wet season, the Yasuni River had higher dissolved oxygen and $\mathrm{pH}$ than other habitats. This may have been attributable to headwater discharges that gave the river transient whitewater features.

\section{Community analyses}

Seasonal sampling yielded highly variable species richness and abundances within the lagoon, river and stream habitats. All study sites had a mix of resident, characteristic species (Table 2) and seasonal species (Figure 7). Dry season sampling in the river and lagoon habitats netted the highest number of species and individuals, as has been reported for other Amazonian lakes (Saint-Paul et al. 2000, Silvano et al. 2000) and rivers (Goulding et al. 1988). In contrast, the highest species richness was found either during the rising or wet seasons for the stream habitats.

No one season yielded the highest rarefaction richness estimates among all habitats. These rarefaction results differ from those of the upper Juruá River in Brazil where Silvano et al. (2000) found higher rarefied estimates during the dry season for lake, river and tributary habitats. However, Silvano et al. (2000) combined samples from different locations and the number of samples varied for each habitat type between seasons.

The grouping of the rising water samples for Tambococha Stream and Yasuni River is explained in part by the high abundances of Hyphessobrycon copelandi and by the 13 shared species like Hemigrammus cf. lunatus and Nemadoras humeralis. In contrast, the rising water Cotoyacu Stream sample clusters alone in part due to the low abundance of $H$. copelandi and the absences of Hyphessobrycon cf. bentosi and $N$. humeralis.

The grouping of wet and falling water season samples within the river and stream samples can be explained by the abundance of a few shared species. For example Pimelodella sp. B and Sternopygus macrurus characterize the grouping of the falling water and wet season Cotoyacu samples, while Hoplosternum littorale and Ancistrus cf. alga characterize the grouping for the wet and falling water season Tambococha samples. Nemadoras trimaculatus, Pimelodella sp. K and Loricaria sp. characterize the wet and falling water season river samples.

The large variability in fish among and within habitats may have been due to sampling methodology and the region's high species richness (Stewart et al. 1987, Galacatos et al. 1996). It is possible that increased numbers of gill nets, minnow traps and sampling days could lower the variability and decrease the rate of new species encountered per additional sample. However, if diel and microhabitat sampling were incorporated, the addition of diurnal and habitat-specific species would probably increase sample variability. While only $16 \%$ of the species of the study's 195 species were rare species (one individual per species), the number of single individuals per sample was high, up to $49 \%$ for Jatuncocha Lagoon, $45 \%$ for the Yasuni River, $63 \%$ for Cotoyacu Stream and $65 \%$ for Tambococha Stream. However, even with the limited sampling methodology, seasonal sampling augmented the number of fish species recorded for the lower Yasuni now (277 species) and for the Napo River Drainage (562 species). Furthermore, the steady increase in species accumulation (Figure 4) indicates that the fish fauna of the lower Yasuni remains under sampled.

Seasonal variation within lagoon, river and stream sites reflected species-specific responses to changing environmental conditions, feeding and reproductive migrations. Junk et al. (1989) and Cox Fernandes (1997) have shown a correlation between fish migrations and changes in oxygen. For example, pimelodids migrate upriver to feed during the dry season (Goulding 1980, Lowe-McConnell 1987, Barthem \& Goulding 1997). However, the pimelodids Brachyplatystoma vaillantii, Hemisorubim platyrhynchos, Platynematichthys notatus, Platystomatichthys sturio and Sorubim lima were found during both falling water and dry seasons, which suggests that within the lower Yasuni these species may begin migrating earlier than the dry season. While studies have noted seasonal variability in fish communities between dry and wet season, the results of this study and Saint-Paul et al. (2000) demonstrate the seasonal variability between rising and falling water seasons. 
Piscivore-Transparency-Morphometry (PTM) model

Seasonal sampling within Jatuncocha Lagoon allowed us to test the PTM model proposed by Rodríguez \& Lewis (1997) for the Orinoco floodplain lakes and tested within the Amazonian floodplain lakes of the Araguaia River, Brazil (Tejerina-Garro et al. 1998). The PTM model predicts that as water transparency and water depth decrease the relative abundance of diurnal, vision-oriented fishes like characiforms should decrease relative to nocturnal or to low light fishes like siluriforms. Thus, according to the PTM model, at the end of the dry season, the lagoon should have a relatively lower percentage of characiform fishes and a higher percentage of siluriform fishes. However, within Jatuncocha Lagoon, siluriforms were abundant during both the wet and dry seasons, while the characiforms were most abundant during the falling water and dry seasons.

These results do not appear to support the PTM model and contrast with those of Rodríguez \& Lewis (1997) and Tejerina-Garro et al. (1998). Sampling methodology may partially explain this contrast. Rodríguez \& Lewis (1997) and TejerinaGarro et al. (1998) used Secchi disc readings to measure transparency and turbidity while our study measured only turbidity. Our sampling methodology concentrated on seasonality and increased sampling effort (12 consecutive days) during each sampling period within a few sites. In contrast, Rodríguez \& Lewis (1997) sampled 20 lakes using electrofishing and Tejerina-Garro et al. (1998) sampled 12 lakes using gill nets. For both of those studies, samples were taken at the beginning and end of the dry season. Their sampling methodology, thus, concentrated on increasing the number of sampled lakes with reduced sampling effort per lake (1 or 2 consecutive days). Differences in the time of sampling could have influenced differences in results. Our sampling period occurred between dusk and dawn, while the sampling periods for both Rodríguez \& Lewis (1997) and Tejerina-Garro et al. (1998) occurred during the day and were biased against nocturnal catfish. The PTM model addresses fish community patterns only during the dry season within large floodplain lakes. Therefore, the PTM model may not be applicable to the blackwater Jatuncocha Lagoon, which experiences polymodal floodpulses typical of smaller headwater regions and is not isolated during the dry season.

\section{Conservation and management considerations}

The lagoon, river and stream habitats of the lower Yasuni were characterized by seasonally dynamic water chemistry, high species diversity and turnover among habitats. The high seasonal variability of these parameters suggests that studies of Amazonian fish communities should include seasonal sampling. Management and assessment of environmental impacts may be difficult in communities where the contribution of rare species is high (Grossman et al. 1990).

The Ecuadorian Amazon, like many other regions within the Amazon basin, is being impacted by human settlement, deforestation and oil production. Such activities affect the aquatic environment that provides not only local water and food resources (Kimberling 1993, Hettler et al. 1996) but also feeding and spawning habitats for migratory species. Furthermore, the presence of migratory pimelodid species within the lower Yasuni supports Barthem \& Goulding's (1997) recommendation that Ecuador be included in the conservation and management of Amazonian catfishes. Studies have already assessed the over-exploitation of Amazonian fisheries (Bayley \& Petrere 1989, Welcomme 1990), however, studies are needed to identify and then assess the status of critical spawning and feeding habitats.

\section{Acknowledgements}

This study was supported by a Fulbright Fellowship to Katerina Galacatos as part of doctoral research. The State University of New York, College of Environmental Science and Forestry, Escuela Politécnica Nacional and the Instituto Ecuatoriano Forestal y de Areas Naturales y Vida Silvestre (INEFAN) generously provided laboratory, logistical and field assistance. The Instituto Nacional de Meteorologia e Hidrologia provided access to rainfall data. This study was also facilitated, in part, by a grant to D. Stewart and R. Barriga from the National Geographic Society. Specimens were collected under permit \#003-IC INEFAN DANVS/VS to Katerina Galacatos. A.S. Flecker, M. Ibarra, N. Ringler, M.A. Rodríguez and two anonymous reviewers provided essential input and critical commentary. 


\section{References}

Almirón, A.E., M.L. García, R.C. Menni, L.C. Protogino \& L.C. Solari. 2000. Fish ecology of a seasonal lowland stream in temperate South America. Mar. Freshw. Res. 51: 265-274.

Angermeier, P.L. \& J.R. Karr. 1983. Fish communities along environmental gradients in a system of tropical streams. Environ. Biol. Fish. 9: 117-135.

Angermeier, P.L. \& M.R. Winston. 1998. Local vs. regional influences on local diversity in stream fish communities of Virginia. Ecology 79: 911-927.

Barthem, R. \& M. Goulding. 1997. The catfish connection: ecology, migration, and conservation of Amazon predators, Columbia University Press, New York. 144 pp.

Bayley, P.B. \& M. Petrere, Jr. 1989. Amazon fisheries: Assessment methods, current status and management options. pp. 385-398. In: D.P. Dodge (ed.) Proceedings of the International Large River Symposium, Can. Spec. Publ. Fish. Aquat. Sci. 106.

Boujard, T. 1992. Space-time organization of riverine fish communities in French Guiana. Environ. Biol. Fish. 34: 235-246.

Clarke, K.R. 1993. Non-parametric multivariate analyses of changes in community structure. Aust. J. Ecol. 18: 117-143.

Cox Fernandes, C.C. 1997. Lateral migration of fishes in Amazon floodplains. Ecol. Freshw. Fish. 6: 36-44.

Galacatos, K., D.J. Stewart \& M. Ibarra. 1996. Fish community patterns of lagoons and associated tributaries in the Ecuadorian Amazon. Copeia 1996: 875-894.

Gehrke, P.C. \& J.H. Harris. 2000. Large-scale patterns in species richness and composition of temperate riverine fish communities, south-eastern Australia. Mar. Freshw. Res. 51: 165-182.

Gorman, O.T. \& J.R. Karr. 1978. Habitat structure and stream fish communities. Ecology 59: 507-515.

Gotelli, N.J. \& G.L. Entsminger. 2001. EcoSim: Null models software for ecology. Version 6.0. Acquired Intelligence Inc. \& Kesey-Bear.

Goulding, M. 1980. The Fishes and the Forest, Explorations in Amazonian Natural History. University of California Press, Berkeley. 280 pp.

Goulding, M., M.L. Carvalho \& E.G. Ferreira. 1988. Rio Negro: Rich life in poor water: Amazonian diversity and foodchain ecology as seen through fish communities, SPB Academic Publishing, The Hague. 200 pp.

Grossman, G.D., J.F. Dowd \& M. Crawford. 1990. Assemblage stability in stream fishes: A review. Environ. Manage. 145: 661-671.

Hayward, D. \& J. Oguntoyinbo. 1987. The Climatology of West Africa, Hutchinson, London. 288 pp.

Henderson, P.A. \& W.G.R. Crampton. 1997. A comparison of fish diversity and abundance between nutrient-rich and nutrientpoor lakes in the Upper Amazon. J. Trop. Ecol. 13: 175-198.

Henderson, P.A. \& H.F. Hamilton. 1995. Standing crop and distribution of fish in drifting and attached floating meadow within an Upper Amazonian varzea lake. J. Fish Biol. 47: 266-276.

Henderson, P.A. \& I. Walker. 1990. Spatial organization and population density of the fish community of the litter banks within a central Amazonian blackwater stream. J. Fish Biol. 37: 401-411.
Hettler, J., B. Lehmann \& L. LeMarie. 1996. Environmental problems of petroleum production in the Amazon lowland of Ecuador. Berliner Geowissenschaftliche Abhandlungen, 183 (A). Selbstverlag Fachbereich Geowissenschaften, Berlin.

Hill, M.O. 1973. Diversity and evenness: A unifying notation and its consequences. Ecology 54: 427-431.

Hurlbert, S.H. 1971. The non-concept of species diversity: A critique and alternative parameters. Ecology 52: 577-596.

Ibarra, M. \& D.J. Stewart. 1989. Longitudinal zonation of sandy beach fishes in the Napo River Basin, eastern Ecuador. Copeia 1989: 369-381.

Jackson, D.A. \& H.H. Harvey. 1989. Biogeographic associations in fish assemblages: Local vs. regional processes. Ecology 70: 1472-1484

Jepsen, D.B. 1997. Fish species diversity in sand bank habitats of a neotropical river. Environ. Biol. Fish. 49: 449-460.

Jongman, R.H.G., C.J.F. Ter Braak \& O.F.R. Van Tongeren. 1995. Data analysis in community and landscape ecology, Cambridge University Press, Cambridge. 299 pp.

Junk, W.J., P.B. Bayley \& R.E. Sparks. 1989. The flood pulse concept in river-floodplain systems. pp. 110-127 In: D.P. Dodge (ed.) Proceedings of the International Large River Symposium, Can. Spec. Publ. Fish. Aquat. Sci. 106.

Keast, A. 1996. Long-term studies of northern temperate freshwater fish communities. pp. 49-72. In: M.L. Cody \& J.A. Smallwood (ed.) Long-term studies of vertebrate communities, Academic Press, Orlando.

Kimberling, J. 1993. Amazon crude. Abya Yala, Quito. 131 pp.

Lowe-McConnell, R.H. 1987. Ecological studies in tropical fish communities. Cambridge University Press, Cambridge. 382 pp.

Magurran, A.E. 1988. Ecological diversity and its measurement. Princeton University Press, Princeton. 179 pp.

Marlier, G. 1967. Ecological studies on some lakes of the Amazon valley. Amazoniana 1: 91-115.

McAleece, N., P.J.D. Lambshead, G.L.J. Paterson \& J.D. Gage. 1997. Biodiversity professional program. The Natural History Museum, London, UK, and the Scottish Association for Marine Science, Oban, Argyll, Scotland.

McCune, B. \& M.J. Mefford. 1999. Multivariate analysis of ecological data, version 3.11. MjM Software, Gleneden Beach, Oregon.

Mérigoux, S. \& D. Ponton. 1999. Spatio-temporal distribution of young fish in tributaries of natural and flow-regulated sections of a neotropical river in French Guiana. Freshw. Biol. 42: 177-198.

Mérigoux, S., D. Ponton \& B. De Mérona. 1998. Fish richness and species-habitat relationship in two coastal streams of French Guiana, South America. Environ. Biol. Fish. 51: 25-39.

Meschiatti, A.J., M.S. Arcifa \& N. Fenerich-Verani. 2000. Fish communities associated with macrophytes in Brazilian floodplain lakes. Environ. Biol. Fish. 58: 133-143.

Petry, P., P.B. Bayley \& D.F. Markle. 2003. Relationships between fish assemblages, macrophytes and environmental gradients in the Amazon River floodplain. J. Fish Biol. 63: 547-579.

Power, M.E. 1983. Grazing ecology of tropical freshwater fishes to different scales of variation in their food. Environ. Biol. Fish. 9: 103-115.

Power, M.E. 1984. Depth distributions of armored catfish: Predator-induced resource avoidance? Ecology 65: 523-528. 
Rodríguez, M.A. \& W.M. Lewis, Jr. 1994. Regulation and stability in fish assemblages of neotropical floodplain lakes. Oecologia 99: 166-180.

Rodríguez, M.A. \& W.M. Lewis, Jr. 1997. Structure of fish assemblages along environmental gradients in floodplain lakes of the Orinoco River. Ecol. Monogr. 671: 109-128.

Saint-Paul, U., J. Zuanon, M.A.V. Correa, M. García, N.N. Fabré, U. Berger \& W.J. Junk. 2000. Fish communities in central Amazonian white- and blackwater floodplains. Environ. Biol. Fish. 57: 235-250.

Sanders, H.L. 1968. Marine benthic diversity: A comparative study. Amer. Nat. 102: 243-282.

Saul, W.G. 1975. An ecological study of fishes at a site in upper Amazonian Ecuador. Proc. Acad. Nat. Sci. Philadelphia 127 93-134.

Silvano, R.A.M., B.D. do Amaral \& O.T. Oyakawa. 2000. Spatial and temporal patterns of diversity and distribution of the Upper Juruá River fish community (Brazilian Amazon). Environ. Biol. Fish. 57: 25-35.

Simberloff, D.S. 1972. Properties of the rarefaction diversity measurement. Amer. Nat. 106: 414-418.

Simpson, E.H. 1949. Measurement of diversity. Nature 163: 688

StatSoft, Inc. 1998. Statistica for Windows. StatSoft, Inc., Tulsa OK.

Stewart, D.J., R.E. Barriga-Salazar \& M. Ibarra. 1987. Ictiofauna de la cuenca del río Napo Ecuador oriental: Lista anotada de especies. Politécnica Serie Biologíca 1: 9-63.
Stewart, D.J., M. Ibarra \& R. Barriga-Salazar. 2002. Comparison of deep-river and adjacent sandy-beach fish assemblages in the Napo River basin, eastern Ecuador. Copeia 2002(2): 333-343.

Strange, E.M., P.B. Moyle \& T.C. Foin. 1992. Interactions between stochastic and deterministic processes in stream fish community assembly. Environ. Biol. Fish. 36: $1-15$

Tejerina-Garro, F.L., R. Fortin \& M.A. Rodríguez. 1998. Fish community structure in relation to environmental variation in floodplain lakes of the Aruaguaia River, Amazon Basin. Environ. Biol. Fish. 51: 399-410.

Vono, V. \& F.A.R. Barbosa. 2001. Habitats and littoral zone fish community structure of two natural lakes in southeast Brazil. Environ. Biol. Fish. 61: 371-379.

Welcomme, R.L. 1990. Status of fisheries in South American rivers. Interciencia 15: 337-345.

Winemiller, K.O. 1996. Dynamic diversity in fish assemblages of tropical rivers. pp. 99-134. In: M.L. Cody \& J.A. Smallwood (ed.) Long-term studies of vertebrate communities, Academic Press, San Diego.

Wootton, J.T. \& M.P. Oemke. 1992. Latitudinal differences in fish community structure and the role of fish herbivory in a Costa Rican stream. Environ. Biol. Fish. 35: 331-319.

Zaret, T.M. \& A.S. Rand. 1971. Competition in stream fishes: Support for the competitive exclusion principle. Ecology 52: 336-342.

Appendix 1. Species by sample matrix. Sites ordered by ordination and classification results. T - Tambococha Stream; C - Cotoyacu Stream; Y - Yasuni River; J - Jatuncocha Lagoon; R - Rising water season; W - Wet season; F - Falling water season; and D - Dry season.

\begin{tabular}{|c|c|c|c|c|c|c|c|c|c|c|c|c|c|c|c|c|c|}
\hline No. & Species & $\begin{array}{l}\mathrm{T} \\
\mathrm{D}\end{array}$ & $\begin{array}{l}\text { C } \\
\text { D }\end{array}$ & $\begin{array}{l}\mathrm{C} \\
\mathrm{R}\end{array}$ & $\begin{array}{l}\mathrm{C} \\
\mathrm{W}\end{array}$ & $\begin{array}{l}\mathrm{C} \\
\mathrm{F}\end{array}$ & $\begin{array}{l}\mathrm{T} \\
\mathrm{R}\end{array}$ & $\begin{array}{l}\mathrm{T} \\
\mathrm{W}\end{array}$ & $\begin{array}{l}\mathrm{T} \\
\mathrm{F}\end{array}$ & $\begin{array}{l}\mathrm{Y} \\
\mathrm{R}\end{array}$ & $\begin{array}{l}\mathrm{Y} \\
\mathrm{W}\end{array}$ & $\begin{array}{l}\mathrm{Y} \\
\mathrm{F}\end{array}$ & $\begin{array}{l}\mathrm{Y} \\
\mathrm{D}\end{array}$ & $\begin{array}{l}\mathrm{J} \\
\mathrm{D}\end{array}$ & $\begin{array}{l}\mathrm{J} \\
\mathrm{R}\end{array}$ & $\begin{array}{l}\mathrm{J} \\
\mathrm{F}\end{array}$ & $\begin{array}{l}\mathrm{J} \\
\mathrm{W}\end{array}$ \\
\hline 1 & Potamotrygon motoro & & & & & & & & & & & & & 2 & & & 1 \\
\hline 2 & Potamotrygon sp. A & & & & & & & & & & & & & 2 & & & 2 \\
\hline 3 & Osteoglossum bicirrhosum & & & & & & & & & & & & & 4 & & & 1 \\
\hline 4 & Pristigaster whiteheadi & & & & & & & & & & & & 5 & & & & \\
\hline 5 & Pellona castelnaeanus & & & & & & & & & & & & 2 & & & 1 & 3 \\
\hline 6 & Illisha amazonica & & & & & & & & & 1 & & 2 & & & & & \\
\hline 7 & Lycengraulis batesii & & & & & & & & & & & 2 & & & & & \\
\hline 8 & Hoplias malabaricus & 3 & 7 & & 4 & 5 & 1 & 3 & 2 & & & & 1 & 5 & & 3 & \\
\hline 9 & Erythrinus erythrinus & 6 & 12 & & & & 2 & 4 & 5 & & & & & & & & 1 \\
\hline 10 & Hoplerythrinus unitaeniatus & & 1 & & 1 & 1 & & 2 & & & & & & & & & \\
\hline 11 & Boulengerella maculata & & & & & & & & & & & & 1 & 1 & & 2 & \\
\hline 12 & Boulengerella cuvieri & & & & & & & & & & & 3 & & & & & \\
\hline 13 & Copeina guttata & 12 & 13 & & & & & & & & & & & & & & \\
\hline 14 & Pyrrhulina sp. A & 10 & 37 & & & & & & & & & & & & & & \\
\hline 15 & Pyrrhulina sp. B & 4 & 5 & & & & & & & & & & & & & & \\
\hline 16 & Pyrrhulina sp. C & 2 & & & & & & & & & & & & & & & \\
\hline 17 & Anodus sp. A & & & & & 2 & & & & & & 3 & 5 & 2 & 6 & 2 & 4 \\
\hline 18 & Hemiodus unimaculatus & & & & & & & & & & & & 3 & 4 & 1 & 2 & 3 \\
\hline 19 & Caenotropus labyrinthicus & & & & & & 3 & & & & & & & & & & \\
\hline 20 & Chilodus punctatus & & & & & & & & & & & & & 1 & & & \\
\hline
\end{tabular}


Appendix 1. (Continued)

\begin{tabular}{|c|c|c|c|c|c|c|c|c|c|c|c|c|c|c|c|c|c|}
\hline No. & Species & $\begin{array}{l}\mathrm{T} \\
\mathrm{D}\end{array}$ & $\begin{array}{l}\text { C } \\
\text { D }\end{array}$ & $\begin{array}{l}\mathrm{C} \\
\mathrm{R}\end{array}$ & $\begin{array}{l}\mathrm{C} \\
\mathrm{W}\end{array}$ & $\begin{array}{l}\mathrm{C} \\
\mathrm{F}\end{array}$ & $\begin{array}{l}\mathrm{T} \\
\mathrm{R}\end{array}$ & $\begin{array}{l}\mathrm{T} \\
\mathrm{W}\end{array}$ & $\begin{array}{l}\mathrm{T} \\
\mathrm{F}\end{array}$ & $\begin{array}{l}\mathrm{Y} \\
\mathrm{R}\end{array}$ & $\begin{array}{l}\mathrm{Y} \\
\mathrm{W}\end{array}$ & $\begin{array}{l}\mathrm{Y} \\
\mathrm{F}\end{array}$ & $\begin{array}{l}\mathrm{Y} \\
\mathrm{D}\end{array}$ & $\begin{array}{l}\mathrm{J} \\
\mathrm{D}\end{array}$ & $\begin{array}{l}\mathrm{J} \\
\mathrm{R}\end{array}$ & $\begin{array}{l}\mathrm{J} \\
\mathrm{F}\end{array}$ & $\begin{array}{l}\mathrm{J} \\
\mathrm{W}\end{array}$ \\
\hline 21 & Laemolyta garmani & & & & & & & & & & & & & & 3 & 1 & \\
\hline 22 & Leporinus agassizi““‘ & & & & & & & & & & & & & & & & 1 \\
\hline 23 & Leporinus cf. mиуscorum & & & 1 & & & 1 & & 1 & & & & & & & & \\
\hline 24 & Leporinus niceforoi & & & & & 1 & & & & & & 1 & 2 & & 1 & & \\
\hline 25 & Leporinus trifasciatus & & & & & & 1 & & & & & & & & & & \\
\hline 26 & Rhytiodus microlepis & & & & & & & & & & & 2 & & & & 1 & \\
\hline 27 & Schizodon fasciatus & & & & & & 1 & & 1 & & & 3 & & & & & \\
\hline 28 & Prochilodus nigricans & & & & & & & & & & & & & 5 & & & \\
\hline 29 & Curimata vittata & & & & & & & & & & & & 1 & 14 & 11 & 35 & 8 \\
\hline 30 & Curimata cisandina & & & & & & & & & 1 & 2 & & & & & 1 & \\
\hline 31 & Curimata roseni & & & & & & & & 3 & 4 & 1 & & 2 & & 4 & 13 & \\
\hline 32 & Curimata aspera & & & & & & & & 2 & & & & & & 1 & 6 & 1 \\
\hline 33 & Curimatopsis macrolepis & & & & & & & & & & & & & 23 & & & \\
\hline 34 & Curimatella alburna & & & & & & 1 & 2 & 2 & 1 & & & & & & 1 & \\
\hline 35 & Curimatella meyeri & & & 1 & & 1 & & 1 & 3 & 1 & & & 11 & & & 65 & \\
\hline 36 & Cyphocharax laticlavius & & & & & & & & & & & & 1 & 3 & & & \\
\hline 37 & Cyphocharax notatus & & & 1 & & 1 & 1 & & 1 & & & & & & 1 & & 4 \\
\hline 38 & Cyphocharax plumbeus & & & & & & & & & & & & 2 & 18 & 9 & 1 & 3 \\
\hline 39 & Cyphocharax spiluropsis & & & & & & & & & & & & 3 & 17 & & 1 & \\
\hline 40 & Potamorhina latior & & & & & & & & & & & & 4 & 12 & 1 & 2 & 5 \\
\hline 41 & Potamorhina altamazonica & & & & & & & & & & & & 1 & 3 & 4 & 4 & 15 \\
\hline 42 & Psectrogaster amazonica & & & & & & 1 & 1 & & 14 & 1 & & 8 & 8 & 12 & 23 & 19 \\
\hline 43 & Psectrogaster essequibensis & & & & & & & 1 & 2 & & & & & 4 & 6 & 101 & \\
\hline 44 & Psectrogaster rutiloides & & & & & & & & & & & & & & 7 & & \\
\hline 45 & Steindachnerina bimaculata & & & & 3 & 5 & & & & 1 & & 2 & 16 & 8 & & 33 & \\
\hline 46 & Curimatid undet. & & & & 1 & & & & & & & & & & & & \\
\hline 47 & Thoracocharax stellatus & & & & & 2 & & & & & & 1 & & & & & \\
\hline 48 & Thoracocharax securis & & & & & 1 & & & & & & & & & & & \\
\hline 49 & Carnegiella schereri & & & & 7 & & & & & & & & & & & & \\
\hline 50 & Carnegiella strigata & & 1 & & & & & 1 & & & & & & & & & \\
\hline 51 & Cynodon gibbus & & & & & & & & & & & & & & 2 & & \\
\hline 52 & Hydrolycus scomberoides & & & & & & 1 & & & 6 & & 2 & 8 & 5 & & 1 & 2 \\
\hline 53 & Rhaphiodon vulpinus & & & & 1 & & & & & & 1 & 3 & 3 & 4 & 3 & 2 & 1 \\
\hline 54 & Acestrocephalus boehlkei & & & & & & & & & & & 1 & & & & & \\
\hline 55 & Acestrorhynchus abbreviatus & & & & & & & & 2 & & & & 2 & 2 & 1 & 2 & \\
\hline 56 & Acestrorhynchus falcirostris & & & & & & & & & & & & & 2 & 1 & & \\
\hline 57 & Acestrorhynchus microlepis & & & & & & & & & & & & 1 & 4 & & & \\
\hline 58 & Aphyocharax sp. & & & & & & & & & 1 & & & & & & & \\
\hline 59 & Astyanax cf. fasciatus & & & & & & & & & & 1 & & & & & & \\
\hline 60 & Bryconella pallidifrons & 20 & & & & & & & & & & & & & & & \\
\hline 61 & Characidium sp. I & & 16 & & & & & & & & & & & & & & \\
\hline 62 & Супоротатиs атаzопиs & & & & 1 & & & & & & & & & & & & \\
\hline 63 & Charax caudimaculatus & & & 3 & 1 & 4 & & & & & & & & 2 & & & \\
\hline 64 & Colossoma тасторотит & & & & & & & & & & & & 2 & & & & \\
\hline 65 & Ctenobrycon hauxwellianus & & & & & & & & & & & 1 & 1 & & & & \\
\hline 66 & Hemigrammus cupreus & & & & & & & & & & & & & 12 & & & \\
\hline 67 & Hemigrammus cf. lunatus & & & 3 & 4 & & 4 & & & 8 & 2 & 7 & 208 & 286 & & 1 & \\
\hline 68 & Hemigrammus luelingi & 3 & 10 & & & & & & & & & & & & & & \\
\hline 69 & Hemigrammus ocellifer & 19 & & & & & & & & & & & & 1 & & & \\
\hline 70 & Hemigrammus unilineatus & & & & 6 & & 5 & & & 1 & & & 3 & 12 & & & \\
\hline 71 & Holoshestes sp. & & & & & & & & & & & & 3 & 7 & & & \\
\hline 72 & Hyphessobrycon cf. bentosi & 3 & & & & & 18 & & & 4 & & & & 25 & & & \\
\hline 73 & Hyphessobrycon copelandi & 6 & & 28 & 5 & & 253 & 1 & & 192 & 25 & 1 & 57 & 612 & & & \\
\hline
\end{tabular}


Appendix 1. (Continued)

\begin{tabular}{|c|c|c|c|c|c|c|c|c|c|c|c|c|c|c|c|c|c|}
\hline No. & Species & $\begin{array}{l}\mathrm{T} \\
\mathrm{D}\end{array}$ & $\begin{array}{l}\text { C } \\
\text { D }\end{array}$ & $\begin{array}{l}\mathrm{C} \\
\mathrm{R}\end{array}$ & $\begin{array}{l}\mathrm{C} \\
\mathrm{W}\end{array}$ & $\begin{array}{l}\mathrm{C} \\
\mathrm{F}\end{array}$ & $\begin{array}{l}\mathrm{T} \\
\mathrm{R}\end{array}$ & $\begin{array}{l}\mathrm{T} \\
\mathrm{W}\end{array}$ & $\begin{array}{l}\mathrm{T} \\
\mathrm{F}\end{array}$ & $\begin{array}{l}\mathrm{Y} \\
\mathrm{R}\end{array}$ & $\begin{array}{l}\mathrm{Y} \\
\mathrm{W}\end{array}$ & $\begin{array}{l}\mathrm{Y} \\
\mathrm{F}\end{array}$ & $\begin{array}{l}\mathrm{Y} \\
\mathrm{D}\end{array}$ & $\begin{array}{l}\mathrm{J} \\
\mathrm{D}\end{array}$ & $\begin{array}{l}\mathrm{J} \\
\mathrm{R}\end{array}$ & $\begin{array}{l}\mathrm{J} \\
\mathrm{F}\end{array}$ & $\begin{array}{l}\mathrm{J} \\
\mathrm{W}\end{array}$ \\
\hline 74 & Hyphessobrycon cf. heterorhabdus & 101 & 29 & & 10 & & & 3 & & & & & & 1 & & & \\
\hline 75 & Hyphessobrycon cf. serpae & & & & & & & & & & 7 & & & & & & \\
\hline 76 & Hyphessobrycon sp. & 1 & & & & & & & & 1 & & & & & & & \\
\hline 77 & Hyphessobrycon cf. tukunai & 13 & 3 & & & & & & & & & & & & & & \\
\hline 78 & Knodus cf. beta & & & & & & & & & & 5 & & & & & & \\
\hline 79 & Moenkhausia cotinho & & & & 2 & & & & & & & & & & & & \\
\hline 80 & Moenkhausia dichroura & & & & 2 & & & 1 & & & 1 & & & 7 & & & \\
\hline 81 & cf. Moenkhausia, undet. juv. & & & & 2 & & & & & & & & & & & & \\
\hline 82 & Myleus sp. A & & & & & & & & & & & & & 2 & & & \\
\hline 83 & Myleus cf. rubripinnis & & & & & & & & & & & & & & 1 & & \\
\hline 84 & Metynnis sp. A & & 1 & & & & & & & & & & & & & & \\
\hline 85 & Mylossoma aureum & & & & & & & & & & & & & 1 & 1 & & \\
\hline 86 & Mylossoma duriventris & & & 1 & & & & 1 & 1 & & & 4 & 2 & 14 & & & \\
\hline 87 & Phenacogaster sp. & & & 6 & & 1 & 1 & & & & 8 & 1 & 33 & 18 & & & \\
\hline 88 & Piaractus brachypomus & & & & & & & & & & & & 1 & & & & \\
\hline 89 & Poptella compressa & & & & 1 & & & & & & & & & 34 & & & \\
\hline 90 & Pygocentrus nattereri & & & & & & & & & & & & & 6 & 1 & 9 & 1 \\
\hline 91 & Roeboides myersii & & & & 1 & & 1 & 2 & & & & 1 & 8 & & & & \\
\hline 92 & Salminus cf. hilarii & & & & & & & & & & & 1 & 1 & & & & \\
\hline 93 & Serrasalmus elongatus & & & & & & & & & & & & & 1 & & & \\
\hline 94 & Serrasalmus rhombeus & & & & & & 1 & 1 & & 2 & 1 & 1 & 3 & 7 & & 4 & 1 \\
\hline 95 & Serrasalmus sp. A & & & & & & & 1 & & & 1 & & & 1 & & & \\
\hline 96 & Stethaprion erythrops & & & & & 1 & & & & & & & 1 & & & & \\
\hline 97 & Tetragonopterus argenteus & & & & & & & & 1 & & & 2 & & & & & \\
\hline 98 & Tetragonopterus chalceus & & & & 1 & & 1 & & 1 & & 1 & & 1 & & & & 1 \\
\hline 99 & Triportheus albus & & & 1 & 1 & & & & & & & & 1 & 3 & 2 & 1 & 1 \\
\hline 100 & Triportheus angulatus & & & & 2 & 1 & & 1 & & & & & 12 & 12 & 7 & 1 & \\
\hline 101 & Triportheus elongatus & & & & & & & 1 & 1 & 1 & 2 & & 18 & 4 & 4 & 9 & 2 \\
\hline 102 & Triportheus culter & & & & & & & & & & & & 2 & & & & \\
\hline 103 & Triportheus pictus & & & 1 & & & & & & & & & & & & & \\
\hline 104 & Tyttobrycon sp. & & & & 2 & & & & & & & & & & & & \\
\hline 105 & Acanthodoras spinosissimus & & & & 1 & & 2 & 1 & 1 & & & & & & 1 & & \\
\hline 106 & Agamyxis pectinifrons & & & & 3 & & & 1 & & & & & & & & & \\
\hline 107 & Amblydoras affinis & & & & 1 & & 1 & & 1 & & & & 1 & 2 & & & \\
\hline 108 & Anadoras grypus & & & & & & & & & & & & & 2 & 5 & & \\
\hline 109 & Doras punctatus & & & & 1 & & & 2 & & & & & & & & & \\
\hline 110 & Nemadoras humeralis & & & & 4 & & 6 & 7 & & 3 & 15 & 6 & 8 & 6 & 7 & 1 & 3 \\
\hline 111 & Nemadoras elongatus & & & & & & & & & & & & & 2 & 1 & & 1 \\
\hline 112 & Nemadoras trimaculatus & & & 2 & & & & 5 & & & 21 & 3 & & & & & \\
\hline 113 & Nemadoras cf. trimaculatus & & & & & & & 4 & & & 1 & & & & & & \\
\hline 114 & Oxydoras niger & & & & & & & & & & & & & & 2 & & \\
\hline 115 & Physopyxis sp. & & & & & & & & & & & & & 1 & & & \\
\hline 116 & Platydoras costatus & & & & 1 & & 1 & & & & & & & & & & \\
\hline 117 & Ageneiosus vittatus & & & & & & & & & & & & 1 & & & & \\
\hline 118 & Ageneiosus ucayalensis & & & & 2 & & & & & & 1 & 6 & 3 & 3 & & & \\
\hline 119 & Ageneiosus inermis & & & & 2 & 1 & & & & 2 & 2 & 4 & 15 & 17 & 1 & & \\
\hline 120 & Ageneiosus sp. D & & & 1 & 4 & & 1 & & & & & & 3 & 2 & 11 & & 4 \\
\hline 121 & Auchenipterichthys thoracatus & & & 1 & & & 2 & & & & & 1 & 2 & & 3 & & \\
\hline 122 & Auchenipterus ambyiacus & & & & & & & & & & & 1 & 2 & 3 & 4 & & 3 \\
\hline 123 & Centromochlus heckelii & & & & & & 1 & & & & 3 & 5 & 2 & 4 & & & 2 \\
\hline 124 & Centromochlus sp. & & & & & & & & & & & 1 & & & 3 & & 1 \\
\hline 125 & Trachelylopterus galeatus & & & & 4 & & 3 & 3 & 1 & 3 & & 1 & 7 & 6 & 3 & 2 & \\
\hline 126 & Tatia intermedia & & & 2 & & & 1 & & & & & & 1 & 2 & & & \\
\hline
\end{tabular}


Appendix 1. (Continued)

\begin{tabular}{|c|c|c|c|c|c|c|c|c|c|c|c|c|c|c|c|c|c|}
\hline No. & Species & $\begin{array}{l}\mathrm{T} \\
\mathrm{D}\end{array}$ & $\begin{array}{l}\text { C } \\
\text { D }\end{array}$ & $\begin{array}{l}\mathrm{C} \\
\mathrm{R}\end{array}$ & $\begin{array}{l}\mathrm{C} \\
\mathrm{W}\end{array}$ & $\begin{array}{l}\mathrm{C} \\
\mathrm{F}\end{array}$ & $\begin{array}{l}\mathrm{T} \\
\mathrm{R}\end{array}$ & $\begin{array}{l}\mathrm{T} \\
\mathrm{W}\end{array}$ & $\begin{array}{l}\mathrm{T} \\
\mathrm{F}\end{array}$ & $\begin{array}{l}\mathrm{Y} \\
\mathrm{R}\end{array}$ & $\begin{array}{l}\mathrm{Y} \\
\mathrm{W}\end{array}$ & $\begin{array}{l}\mathrm{Y} \\
\mathrm{F}\end{array}$ & $\begin{array}{l}\mathrm{Y} \\
\mathrm{D}\end{array}$ & $\begin{array}{l}\mathrm{J} \\
\mathrm{D}\end{array}$ & $\begin{array}{l}\mathrm{J} \\
\mathrm{R}\end{array}$ & $\begin{array}{l}\mathrm{J} \\
\mathrm{F}\end{array}$ & $\begin{array}{l}\mathrm{J} \\
\mathrm{W}\end{array}$ \\
\hline 127 & Brachyplatystoma vaillantii & & & & & & & & & & & 1 & 1 & & & & \\
\hline 128 & Brachyrhamdia cf. marthae & & & & & 1 & & & & & & & & & & & \\
\hline 129 & Calophysus macropterus & & & & & & & & & & & & 3 & 2 & & & \\
\hline 130 & Gladioglanis conquistidor & 24 & 13 & & & & & & & & & & & & & & \\
\hline 131 & Hemisorubim platyrhynchos & & & & & & & & & & & & 4 & & & 1 & \\
\hline 132 & Hypophthalmus sp. A & & & & & & & & & & & & & & 1 & & 1 \\
\hline 133 & Hypophthalmus sp. B & & & & & & & & & & 1 & & & & & & \\
\hline 134 & Imparfinis sp. & & & & 1 & & & & & & & & & & & & \\
\hline 135 & Pimelodella sp. C & & & & & & 2 & & & & & & & & & & \\
\hline 136 & Pimelodella sp. F & & & 7 & 13 & 18 & 1 & 1 & 1 & 3 & 9 & 19 & 9 & 4 & & 1 & \\
\hline 137 & Pimelodella sp. G & & & 1 & & & & & & 6 & 3 & 4 & 15 & & & & \\
\hline 138 & Pimelodella sp. $\mathrm{H}$ & & & & & & & & & & & 1 & & & & & \\
\hline 139 & Pimelodella sp. I & & & & 1 & 5 & 2 & & & & & & 1 & & & & \\
\hline 140 & Pimelodella sp. K & & & & & & & & & & 9 & 7 & 11 & & & & 1 \\
\hline 141 & Pimelodina flavipinnis & & & & & & & & & & & & & & 2 & & \\
\hline 142 & Pimelodus sp. C & & & & 1 & & & & & & & 1 & 4 & & & 1 & 1 \\
\hline 143 & Pinirampus pirinampu & & & & & & & & & 2 & & 1 & & & & & \\
\hline 144 & Platynematichthys notatus & & & & & & & & & & & & 1 & & & & \\
\hline 145 & Platystomatichthys sturio & & & & & & & & & & & 3 & 1 & & & & \\
\hline 146 & Pseudopimelodus sp. & & & & 1 & & & & & & & & & & & & \\
\hline 147 & Rhamdia sp. & & 1 & & 3 & 1 & & 1 & 1 & & & & 1 & & & & \\
\hline 148 & Sorubim lima & & & & & & & & & & & 2 & & & & & \\
\hline 149 & Sorubim sp. A & & & & & & 1 & 1 & & 1 & 1 & 1 & 2 & & & 1 & \\
\hline 150 & Sorubim elongatus & & & & & & & & & 1 & & & & & & & \\
\hline 151 & Hemicetopsis candiru & & & & 1 & & & & & & & & & & & & \\
\hline 152 & Bunocephalus bifidus & 15 & 12 & & & & & & & & & & & & & & \\
\hline 153 & Bunocephalus verrucosus & & 3 & & 1 & & & & & & & & & 1 & & & \\
\hline 154 & Branchioica sp. & & & & & & & & & & & & & 1 & & & 3 \\
\hline 155 & Tridentopsis sp. & 1 & 11 & & & & & & & & & & & & & & \\
\hline 156 & Callichthys callichthys & & & & & & 1 & 2 & & & & & & & & & \\
\hline 157 & Hoplosternum littorale & & & & 1 & & & 15 & 2 & & 13 & & & & & & \\
\hline 158 & Dianema longibarbis & & & & 1 & & 1 & & & & & & & & & & \\
\hline 159 & Megalechis thoracata & 1 & & & & & & 2 & & & & & & & & & 1 \\
\hline 160 & Ancistrus cf. alga & & & & & & 1 & 4 & 1 & & & & & & & & \\
\hline 161 & Hypostomus emarginatus & & & & & & & & & 10 & & 14 & 25 & & & & \\
\hline 162 & Hypostomus sp. & & & & 1 & & & 1 & & & 2 & & 2 & 1 & & & \\
\hline 163 & Lamontichthys filamentosus & & & & & & & & & 1 & & & & & & & \\
\hline 164 & Loricaria simillima & & & & & & & & & 1 & & & & & & & \\
\hline 165 & Loricaria sp. & & & & & & & & & & 5 & 2 & 3 & & & & \\
\hline 166 & Otocinclus macrospilus & & & & & & & & & & & 3 & & & & & \\
\hline 167 & Peckoltia ucayalensis & & & & & 1 & & & & & 1 & 4 & 1 & & & & \\
\hline 168 & Rineloricaria sp. & & & & & & & & & & & & & & & & 1 \\
\hline 169 & Sturisoma guentheri & & & & & & & & & 4 & & 3 & 13 & & & & \\
\hline 170 & Gymnotus carapo & & 4 & & & & 1 & 1 & 2 & & & & & & & & 1 \\
\hline 171 & Electrophorus electricus & & & & & & & & & & 1 & & & & & & \\
\hline 172 & Apteronotus macrostomus & & & & & & & & & & & & 2 & & & & \\
\hline 173 & Sternarchogiton $\mathrm{sp}$. & & & & & & & & & & & & 1 & & & & \\
\hline 174 & Rhamphichthys sp. & & & & 2 & & & & & & & 3 & & & 2 & 1 & \\
\hline 175 & Eigenmannia cf. limbatus & & & & 2 & 1 & & & 1 & & & 2 & 1 & 2 & 2 & & \\
\hline 176 & Rhabdolichops troscheli & & & & & & & & & & & & & 1 & & & \\
\hline 177 & Sternopygus macrurus & & & 1 & 8 & 3 & 2 & 6 & & & & 2 & 6 & 1 & & 2 & 1 \\
\hline 178 & Steatogenys elegans & & & & & & & & 1 & & & & & & & & \\
\hline 179 & Rivulus limoncochae & 8 & 3 & & & & & & & & & & & & & & \\
\hline 180 & Plagioscion squamosissimus & & & & & & 2 & 1 & & 3 & 39 & 6 & 12 & 24 & & 6 & 3 \\
\hline
\end{tabular}


Appendix 1. (Continued)

\begin{tabular}{|c|c|c|c|c|c|c|c|c|c|c|c|c|c|c|c|c|c|}
\hline No. & Species & $\begin{array}{l}\mathrm{T} \\
\mathrm{D}\end{array}$ & $\begin{array}{l}\text { C } \\
\text { D }\end{array}$ & $\begin{array}{l}\mathrm{C} \\
\mathrm{R}\end{array}$ & $\begin{array}{l}\mathrm{C} \\
\mathrm{W}\end{array}$ & $\begin{array}{l}\mathrm{C} \\
\mathrm{F}\end{array}$ & $\begin{array}{l}\mathrm{T} \\
\mathrm{R}\end{array}$ & $\begin{array}{l}\mathrm{T} \\
\mathrm{W}\end{array}$ & $\begin{array}{l}\mathrm{T} \\
\mathrm{F}\end{array}$ & $\begin{array}{l}\mathrm{Y} \\
\mathrm{R}\end{array}$ & $\begin{array}{l}\mathrm{Y} \\
\mathrm{W}\end{array}$ & $\begin{array}{l}\mathrm{Y} \\
\mathrm{F}\end{array}$ & $\begin{array}{l}\mathrm{Y} \\
\mathrm{D}\end{array}$ & $\begin{array}{l}\mathrm{J} \\
\mathrm{D}\end{array}$ & $\begin{array}{l}\mathrm{J} \\
\mathrm{R}\end{array}$ & $\begin{array}{l}\mathrm{J} \\
\mathrm{F}\end{array}$ & $\begin{array}{l}\mathrm{J} \\
\mathrm{W}\end{array}$ \\
\hline 181 & Aequidens tetramerus & 4 & 6 & & & & & & 5 & & & & & & & & \\
\hline 182 & Aequidens $\mathrm{cf}$. diadema & & & & & & & 1 & & & & & & & & & \\
\hline 183 & Apistogramma cruzi & 2 & & & & & 1 & & & & & & & 1 & & & \\
\hline 184 & Astronotus ocellatus & & & & & & & & 1 & & & & & & & & \\
\hline 185 & Burjurquina sp. & & & & & & & & & & & & 1 & & & & \\
\hline 186 & Cichla monoculus & & & 1 & & & & & & & & & & & & & \\
\hline 187 & Crenicichla anthurus & & & & 1 & & 1 & & 1 & & & & & & & & \\
\hline 188 & Crenicichla cincta & & & & & 5 & & & & & 1 & & & & & 2 & 2 \\
\hline 189 & Crenicichla proteus & & & & 2 & 1 & & 2 & 1 & 1 & & & & & & & \\
\hline 190 & Heros efasciatus & & & & & & & & 1 & & & & & & & & \\
\hline 191 & Hypselecara temporalis & & & & & & 1 & 2 & 2 & & & & & & & & \\
\hline 192 & Laetacara flavilabris & & 1 & & & & & & & & & & & & & & \\
\hline 193 & Satanoperca jurupari & & & & & & & & & & & & & 1 & & & \\
\hline 194 & Hypoclinemus mentalis & & & 1 & & & & & & & & & 4 & 1 & & 1 & 5 \\
\hline 195 & Colomesus asellus & & & & & & & & & & & & & & 2 & & \\
\hline
\end{tabular}

